\title{
A multi-proxy analysis of Late Quaternary ocean and climate variability for the Maldives, Inner Sea
}

\author{
Dorothea Bunzel $^{1}$, Gerhard Schmiedl ${ }^{1}$, Sebastian Lindhorst ${ }^{1}$, Andreas Mackensen ${ }^{2}$, Jesús Reolid ${ }^{1}$, Sarah Romahn ${ }^{1}$, \\ and Christian Betzler ${ }^{1}$ \\ ${ }^{1}$ Center for Earth System Research and Sustainability (CEN), Institute for Geology, \\ University of Hamburg, 20146 Hamburg, Germany \\ ${ }^{2}$ Alfred Wegener Institute (AWI), Helmholtz Centre for Polar and Marine Research, \\ 27568 Bremerhaven, Germany
}

Correspondence: Dorothea Bunzel (dorothea.bunzel@uni-hamburg.de)

Received: 24 March 2017 - Discussion started: 3 April 2017

Revised: 25 August 2017 - Accepted: 30 October 2017 - Published: 13 December 2017

\begin{abstract}
As a natural sediment trap, the marine sediments of the sheltered central part of the Maldives Inner Sea represent an exceptional archive for paleoenvironmental and climate changes in the equatorial Indian Ocean. To evaluate the complex interplay between high-latitude and monsoonal climate variability, related dust fluxes, and regional oceanographic responses, we focused on $\mathrm{Fe} / \mathrm{Al}$, Ti / $\mathrm{Al}$ and $\mathrm{Si} / \mathrm{Ca}$ ratios as proxies for terrigenous sediment delivery and total organic carbon (TOC) and Br XRF counts as proxies for marine productivity. Benthic foraminiferal fauna distributions, grain size and stable $\delta^{18} \mathrm{O}$ and $\delta^{13} \mathrm{C}$ data were used for evaluating changes in the benthic ecosystem and changes in the intermediate water circulation, bottom water current velocity and oxygenation.

Our multi-proxy data record reveals an enhanced dust supply during the glacial intervals, causing elevated $\mathrm{Fe} / \mathrm{Al}$ and $\mathrm{Si} / \mathrm{Ca}$ ratios, an overall coarsening of the sediment and an increasing amount of agglutinated benthic foraminifera. The enhanced dust fluxes can be attributed to higher dust availability in the Asian desert and loess areas and its transport by intensified winter monsoon winds during glacial conditions. These combined effects of wind-induced mixing of surface waters and dust fertilization during the cold phases resulted in an increased surface water productivity and related organic carbon fluxes. Thus, the development of highly diverse benthic foraminiferal faunas with certain detritus and suspension feeders was fostered. The difference in the $\delta^{13} \mathrm{C}$ signal between epifaunal and deep infaunal benthic foraminifera reveals intermediate water oxygen concentrations between ap-
\end{abstract}

proximately 40 and $100 \mu \mathrm{mol} \mathrm{kg}{ }^{-1}$ during this time. The precessional fluctuation pattern of oxygen changes resembles that from the deep Arabian Sea, suggesting an expansion of the oxygen minimum zone (OMZ) from the Arabian Sea into the tropical Indian Ocean with a probable regional signal of strengthened winter-monsoon-induced organic matter fluxes and oxygen consumption further controlled by the varying inflow intensity of the Antarctic Intermediate Water (AAIW). In addition, the bottom water oxygenation pattern of the Maldives Inner Sea reveals a long phase of reduced ventilation during the last glacial period. This process is likely linked to the combined effects of generally enhanced oxygen consumption rates during high-productivity phases, reduced AAIW production and the restriction of upper bathyal environments in the Inner Sea during sea-level lowstands. Thus, our multi-proxy record reflects a close linkage between the Indian monsoon oscillation, intermediate water circulation, productivity and sea-level changes on orbital timescale.

\section{Introduction}

Sedimentation and biogeochemical processes in the tropical and subtropical northern Indian Ocean are closely linked to the intensity and seasonal changes of the Indian monsoon system. From June to October, the region is dominated by the south-western (SW) monsoon, while the north-eastern (NE) monsoon operates from December to April (Wyrtki, 1973; Schott and McCreary, 2001). During the SW monsoon, 
coastal and open-ocean upwelling results in maximum surface water productivity and related organic matter fluxes in the Arabian Sea (Nair et al., 1989; Rixen et al., 1996). At the same time, the South-west Monsoon Current (SMC) transports high-saline surface waters from the Arabian Sea into the equatorial region (Schott and McCreary, 2001). The SW summer monsoon variability is strongly coherent over the precessional band and reveals a close but lagged response to Northern Hemisphere summer insolation maxima (Clemens and Prell, 2003). In comparison, during the NE winter monsoon the ocean current system reverses and the North-east Monsoon Current (NMC) transports lower-saline surface waters from the Bay of Bengal into the western Indian Ocean. Thus, during the NE monsoon, elevated chlorophyll $a$ concentrations are mainly restricted to the Indian western coast and the Maldives area, while chlorophyll $a$ strongly decreases in the Arabian Sea at the same time (Sasamal, 2007; de Vos et al., 2014; NASA Goddard Space Flight Center, 2014).

Evaluations of deep-sea sediment archives from the Arabian Sea deliver not only comprehensive information on the pacing and intensity of the Indian summer monsoon on orbital timescales (Clemens and Prell, 1990, 2003; Clemens et al., 1991, 1996; Ziegler et al., 2010; Caley et al., 2011a), but also show variance within orbital bands to more rapid climate shifts on suborbital timescales (Schulz et al., 1998; Altabet et al., 2002; Gupta et al., 2003; Pichevin et al., 2007; Böning and Bard, 2009; Caley et al., 2013; Deplazes et al., 2013). Records from the equatorial Indian Ocean provide a more diverse and partly contradictory picture since this region is not only influenced by the summer and winter monsoons but also by the strength of Indian Ocean Equatorial Westerlies (IEW), which are stronger during the intermonsoon seasons in spring and fall and are inversely related to the Indian Ocean Dipole (Hastenrath et al., 1993; Beaufort et al., 2001). Variations in surface water properties at a site close to the Maldives platform revealed maximum productivity at times of enhanced winter monsoon winds associated with precessional maxima in ice volume (Rostek et al., 1997). By contrast, an upper bathyal benthic foraminiferal record from the Maldives Ridge suggests that Late Quaternary changes in organic matter fluxes are either driven by summer monsoon winds (Sarkar and Gupta, 2009) or linked to changes in the IEW strength (Sarkar and Gupta, 2014). The precessional variability in productivity records from the equatorial Indo-Pacific Ocean has been attributed to the influence of low-latitude insolation on the IEW strength and on the long-term dynamics of the El Niño-Southern Oscillation (ENSO; Beaufort et al., 1997, 2001).

The seasonally reversing circulation pattern of the modern monsoon system was established $\sim 12.9 \mathrm{Ma}$, as indicated by the onset of drift deposition in the Maldives Inner Sea (Betzler et al., 2016). However, early aeolian dust deposits at the Maldives between $\sim 20$ and $12.9 \mathrm{Ma}$ can be attributed to a weak proto-monsoon when prevailing wind systems were strong enough to transport dust material into the northern Indian Ocean, but not sufficiently strong to promote the water currents that generate drift deposits (Aston et al., 1973; Guo et al., 2002; Grand et al., 2015; Betzler et al., 2016). Since the early Miocene, the deposition of aeolian particles to the Maldives increased stepwise, coinciding with the onset of Asian desertification derived from loess deposits in northern China (Guo et al., 2002; Betzler et al., 2016). On a regional scale, these changes in aridity were caused by various factors, including the Tibetan-Himalayan plateau uplift, which intensified 25-20 Ma and changed wind circulation patterns due to the uplifted topography (Ruddiman and Kutzbach, 1989; Manabe and Broccoli, 1990; Harrison et al., 1992; Guo et al., 2002). However, little detailed information is available about the variability of aeolian dust delivery or its provenance and linkage to prevailing monsoon circulation patterns in the Maldives area since the Late Quaternary.

In addition to the aeolian influx, sea-level fluctuations and bottom currents played a significant role in the evolution of the sedimentary system of the Maldives (Betzler et al., 2009, 2013a, 2016; Lüdmann et al., 2013). Relative sea-level highstands caused a flooding of the carbonate platforms and an export of shallow-water carbonate sediments into the adjacent basins, whereas sea-level lowstands caused an exposure of the platforms and likely a strengthened restriction of the Inner Sea area (Schlager et al., 1994; Paul et al., 2012; Lüdmann et al., 2013; Betzler et al., 2013b, 2016). Moreover, previous studies have shown that during times of restricted water circulation in the Inner Sea, the deposition of organic matter was likewise facilitated (Betzler et al., 2016). In recent times, the decay of organic matter in the water column and the generally reduced ventilation of regional subsurface waters in the Indian Ocean results in the development of a strong oxygen minimum zone (OMZ) between 200 and $1200 \mathrm{~m}$ of water depth (Reid, 2003; Stramma et al., 2008). This oxygen depletion is fostered by the semi-enclosed nature of the northern Indian Ocean, the long pathway of intermediate water from its main formation sites at $40^{\circ} \mathrm{S}$ in the central South Indian Ocean (Antarctic Intermediate Water, AAIW) and Indonesia (Indonesian Intermediate Water, IIW; Olson et al., 1993; You, 1998), and the contribution of low-oxygen outflow waters from the Red Sea and the Persian Gulf (Jung et al., 2001; Prasad and Ikeda, 2001). The OMZ extends from the Arabian Sea into the equatorial Indian Ocean. While oxygen concentrations in the Arabian Sea can be as low as $0.1 \mathrm{mLL}^{-1}$ (or $5 \mu \mathrm{mol} \mathrm{kg}{ }^{-1}$; Reid, 2003), they still reach low oxic values of around $1 \mathrm{mLL}^{-1}$ (or $45 \mu \mathrm{mol} \mathrm{kg}{ }^{-1}$ ) in 500 to $1000 \mathrm{~m}$ of water depth in the Maldives region (Weiss et al., 1983; Reid, 2003). Phases of an intensified OMZ in the northern Indian Ocean are controlled by changes in the ventilation of both intermediate- and deepwater masses (Schmiedl and Leuschner, 2005; Ziegler et al., 2010; Das et al., 2017) and by regional oxygen consumption responding to monsoon-driven upwelling and high surface productivity (e.g. Reichart et al., 1998; Den Dulk et al., 
2000; Das et al., 2017). This addresses the ongoing debates on whether fluctuations of the OMZ in the Maldives area can be linked to a basin-wide change in the composition of intermediate waters and/or super-regional oceanic processes, respectively. And what is the role of regional sea-level changes in this context?

Here we present a multi-proxy data set on the links between the climate variability, ocean circulation, sedimentation and biogeochemical processes of the Maldives Inner Sea. Specifically, our study addresses the following questions: (1) what impact did orbital-scale changes in the Indian monsoon have on the dust fluxes and marine environments of the Maldives? (2) How did global sea-level changes influence the sedimentation processes and benthic ecosystems of the Maldives Inner Sea? (3) Can we trace the influence of changes in the configuration of intermediate waters, and how are these changes related to super-regional oceanographic processes? The Maldives Inner Sea is ideally situated to answer these questions because it lies in the central part of the Indian Ocean and is therefore situated in a region influenced by the different processes introduced above. The Maldives also appear as an ideal place to trace back paleoceanographic variations in time, as seismic surveys have shown that the Maldives are comparable to a large natural sediment trap with a continuous succession since the Neogene (Betzler et al., 2009, 2013a, b, 2016; Lüdmann et al., 2013).

\section{Material and methods}

\subsection{Sediment cores and material descriptions}

For this study, two sediment cores were retrieved from different sites in the Inner Sea of the Maldives (Fig. 1). The $5.97 \mathrm{~m}$ long sediment core SO236-052-4 was obtained by means of a gravity corer in the framework of R/V SONNE cruise SO236 in August 2014, east of the North Ari Atoll in the central part of the Inner Sea $\left(03^{\circ} 55.09^{\prime} \mathrm{N} ; 73^{\circ} 08.48^{\prime} \mathrm{E}\right)$ from a water depth of $382 \mathrm{~m}$. The $12.94 \mathrm{~m}$ long sediment core M74/41143 is a piston core from R/V METEOR cruise M74/4, obtained in 2007 from east of the Goidhoo Atoll $\left(04^{\circ} 49.50^{\prime} \mathrm{N}\right.$; $73^{\circ} 05.04^{\prime} \mathrm{E}$ ) at a water depth of $387 \mathrm{~m}$ (Fig. 1). For comparison with the gravity core, this study is focused on the first $6.00 \mathrm{~m}$ of core M74/4-1143.

The sediment of core SO236-052-4 consists of an alternation of non-lithified fine-grained ooze with abundant pteropods, sponge spicules, planktonic and benthic foraminifera, and echinoid remains, with minor otolites and fragments of gastropods and bivalves. There are some local intervals that present up to $4 \mathrm{~cm}$ of bioclast including solitary corals and thin-shelled bivalves. The entire succession is intensely reworked by bioturbation. Just a few primary structures, usually the main boundaries between facies, are preserved (i.e. the sharp contacts at $2.35 \mathrm{~m}$ below sea floor, mb.s.f., and at $3.90 \mathrm{~m}$ b.s.f.). Discrete bur-

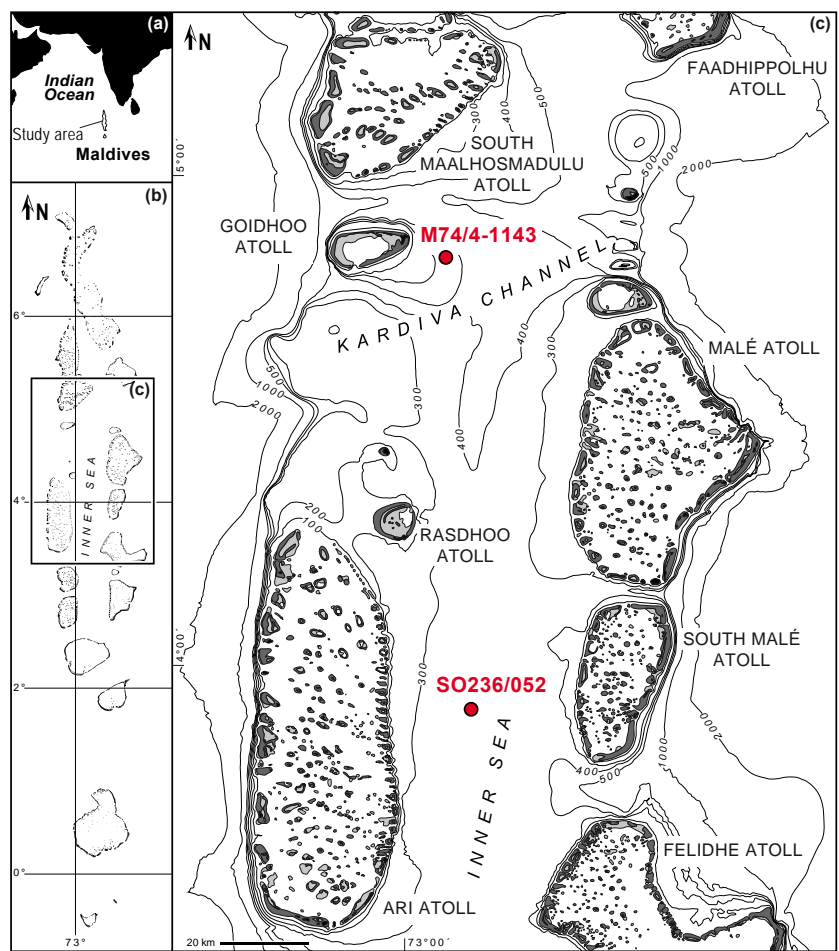

Figure 1. Location maps of the Maldives archipelago in the Indian Ocean (a, b) and the setting of the study area (c) (modified after Betzler et al., 2013a), showing the location of sediment core M74/41143 in the Kardiva Channel and core SO236-052-4 in the central part of the Inner Sea (red circles).

rows are scarce. The succession recovered at site M74/41143 has been described by Betzler et al. (2013b). The core mainly consists of periplatform ooze containing planktonic foraminifera, pteropods, otoliths, mollusc remains, benthic foraminifera, sponge spicules, and echinoid debris. Down the core, light and dark coloured greenish to olive grey intervals alternate (Betzler et al., 2013b).

\subsection{Geochemical analyses}

Scanning X-ray fluorescence (XRF) element analysis of core SO236-052-4 was carried out at the MARUM, University of Bremen, using an Avaatech XRF Core Scanner II. Element analysis was performed at $1 \mathrm{~cm}$ intervals using generator settings of $50 \mathrm{kV}(1.0 \mathrm{~mA}$ current), $30 \mathrm{kV}(1.0 \mathrm{~mA})$ and $10 \mathrm{kV}(0.2 \mathrm{~mA})$ and a sampling time of $20 \mathrm{~s}$ per measurement. Raw data spectra were processed using the software package WIN AXIL. Element ratios $(\mathrm{Fe} / \mathrm{Al}, \mathrm{Ti} / \mathrm{Al}, \mathrm{Si} / \mathrm{Ca}$, $\mathrm{Sr} / \mathrm{Ca}$ ) were calculated and used for environmental interpretations following Martin et al. (1991), Zhang et al. (1993), Boyd et al. (2000), Gao et al. (2001), Lourens et al. (2001), Jickells et al. (2005), Itambi et al. (2009) and Croudace and Rothwell (2015). Bromine (Br) XRF counts were used as an 
indicator of variability in the marine organic carbon (MOC) content (Ziegler et al., 2008; Caley et al., 2013).

The total inorganic carbon (TIC, calcium carbonate) and total organic carbon (TOC) contents of core SO236-052-4 were measured at $5 \mathrm{~cm}$ spacing. The carbon content of the grain size fraction $<63 \mu \mathrm{m}$ was determined using a LECO DR144 carbon analyser. All samples were freeze-dried. Subsequently, one subsample was measured at $1350^{\circ} \mathrm{C}$ to obtain the total carbon (TC) content. A second subsample was heated to $550^{\circ} \mathrm{C}$ for $5 \mathrm{~h}$ to remove the organic carbon prior to measurement in the LECO; this gave the TIC content. The difference between the TC and TIC contents is regarded as the TOC content. The calcium carbonate contents were then calculated from the total inorganic carbon content as follows: $\mathrm{CaCO}_{3}(\%)=(\mathrm{TC}-\mathrm{TOC}) \times 8.33$, where 8.33 is the atomic proportion of carbon in $\mathrm{CaCO}_{3}$ (e.g. Müller et al., 1994; di Primio and Leythaeuser, 1995; Romero et al., 2006).

\subsection{Grain size analyses}

For bulk grain size analysis, core SO236-052-4 was sampled equidistantly $\left(1.5 \mathrm{~cm}^{3}\right.$ every $\left.1 \mathrm{~cm}\right)$. Samples were wet-sieved $(2000 \mu \mathrm{m})$ to remove very coarse particles and subsequently suspended in water with the addition of a $0.05 \%$ solution of tetrasodium diphosphate decahydrate as a dispersant.

The mean grain size of the non-carbonate fraction between 10 and $63 \mu \mathrm{m}$, the sortable silt, has been shown to be a reliable proxy for paleocurrent strength in predominantly siliciclastic sediments (Manighetti and McCave, 1995; McCave et al., 1995a, b; Hall et al., 1998; Bianchi et al., 1999; McCave and Hall, 2006). The method makes use of the noncarbonate fraction only and is therefore expected to be unaffected by primary carbonate production and burial diagenesis. Samples for the determination of the sortable silt component (ca. $20 \mathrm{~cm}^{3}$ each) were taken equidistantly (in core M74/4-1143 at $5 \mathrm{~cm}$ intervals down to $1 \mathrm{~m}$ of core depth and at $10 \mathrm{~cm}$ intervals underneath, and at $5 \mathrm{~cm}$ downcore intervals in core SO236-052-4). Subsequently to wet-sieving, the fraction $<63 \mu \mathrm{m}$ was cooked in $\mathrm{H}_{2} \mathrm{O}_{2}$ to remove the organic portion and treated with $1 \mathrm{M} \mathrm{Ca}_{3} \mathrm{COOH}$ to dissolve the carbonate. Biogenic opal was removed with $2 \mathrm{M} \mathrm{NaHCO}_{3}$. The remainder was dispersed in water for grain size determination.

Bulk grain size and sortable silt measurements were done using a Helos KF Magic Laser particle size analyser and measuring ranges of either $0.5 / 18-3500 \mu \mathrm{m}$ (for bulk grain size) or $0.25-87.5 \mu \mathrm{m}$ (for the non-carbonate fraction). To ensure the accuracy of the measurements and the absence of a long-term instrumental drift, an in-house grain size standard was measured regularly. Grain size statistics are based on the graphical method (Folk and Ward, 1957) and were calculated using the software GRADISTAT (Blott and Pye, 2001).

\subsection{Foraminiferal faunal and stable isotope analyses}

For stable isotope analyses, core SO236-052-4 was sampled at $5 \mathrm{~cm}$ spacing, and for benthic foraminiferal faunal analysis at $10 \mathrm{~cm}$ spacing. All samples were wet-sieved over a $63 \mu \mathrm{m}$ screen and the residues were subsequently dried at $38^{\circ} \mathrm{C}$. The benthic foraminiferal analysis was carried out on the $>125 \mu \mathrm{m}$ size fraction and based on allocate splits in order to obtain approximately 300 tests. Genus and species identifications were mainly based on Loeblich and Tappan (1988), Hottinger et al. (1993), Jones (1994), Debenay (2012), Milker and Schmiedl (2012) and Holbourn et al. (2013). The genera Cymbaloporetta and Tretomphaloides were summarized as meroplanktonic benthic foraminifera (BF) since they are known to have planktonic drift phases as part of their dispersal strategy (Banner et al., 1985; Alve, 1999). For analysis based on the test material, all individuals of the foraminiferal orders Astrorhizida, Lituolida and Textulariida were summarized as agglutinated BF.

Benthic foraminiferal assemblages were defined by Qmode principal component analysis (PCA) with varimax rotation using the software SYSTAT version 5.2.1. Following Schmiedl et al. (1997), only foraminiferal taxa with percentages of $\geq 1 \%$ in at least one sample and/or taxa which occur at least in two samples were used for the statistical analysis. Loadings $\geq 0.5$ were defined as significant (Backhaus et al., 2008). The Shannon-Wiener diversity index $H(S)$ was calculated after Murray (2006) based on the function $H(S)=(-1) \sum_{i=1}^{S} p_{i} \times \ln \left(p_{i}\right)$, where $S$ is the species number and $p_{i}$ is the relative abundance of the $i$ th species.

Stable oxygen and carbon isotope records were generated for planktonic and benthic foraminifera. Approximately 10 tests of the planktonic foraminifer Globigerinoides ruber (white) were selected from the 250-350 $\mu \mathrm{m}$ size fraction of core SO236-052-4. Stable isotope data for G. ruber (white) of core M74/4-1143 were taken from Betzler et al. (2013b). In addition, approximately 2-5 tests of the epibenthic foraminifera Cibicides mabahethi and the deep infaunal species Globobulimina affinis s.l. were selected from the size fraction $>125 \mu \mathrm{m}$ of core SO236-052-4. Stable oxygen and carbon isotope analyses were performed with a Finnigan MAT253 gas mass spectrometer coupled to the automatic carbonate preparation device Kiel IV. The mass spectrometer was calibrated to the PDB scale via international standard NBS19, and results are given in $\delta$ notation versus VPDB. Based on measurements of an internal laboratory standard (Solnhofen limestone) together with samples over a 1 -year period, precision was better than $0.08 \%$ for $\delta^{18} \mathrm{O}$ and $0.06 \%$ for $\delta^{13} \mathrm{C}$.

For core SO236-052-4 changes in bottom water oxygen concentrations were estimated based on the $\delta^{13} \mathrm{C}$ difference between the epifaunal $(C$. mabahethi $=\mathrm{Cm})$ and deep infaunal $(G$. affinis s.l. $=G a$ ) benthic foraminifera using the function $\Delta \delta^{13} \mathrm{C}=0.00772 \times\left[\mathrm{O}_{2}\right]+0.41446$, wherein $\left[\mathrm{O}_{2}\right]$ concentrations between 55 and $235 \mu \mathrm{mol} \mathrm{kg} \mathrm{kg}^{-1}$ have shown 
a strong linear relationship between bottom water $\left[\mathrm{O}_{2}\right]$ and $\Delta \delta^{13} \mathrm{C}$ (Hoogakker et al., 2015). We also applied this function to the low $\left[\mathrm{O}_{2}\right]$ values $\left(\left[\mathrm{O}_{2}\right]<55 \mu \mathrm{mol} \mathrm{kg}{ }^{-1}\right)$ because such a relationship may also exist for low $\left[\mathrm{O}_{2}\right]$ values and $\Delta \delta^{13} \mathrm{C}$, although this is not investigated by Hoogakker et al. (2015). For $\left[\mathrm{O}_{2}\right]$ reconstruction two $\delta^{13} \mathrm{C}$ values of core SO236-052-4 (at 0.17 and $130.92 \mathrm{ka}$ ) have not been considered due to the weak validity in the $\delta^{13} \mathrm{C}_{G a}$ signal. For comparison, oxygen concentration changes in a deepsea sediment core from an Arabian Sea site (GeoB3004; $1803 \mathrm{~m}$ of water depth) were taken from Schmiedl and Mackensen (2006). These data are based on the difference between the epifaunal Cibicidoides wuellerstorfi $(C w)$ and $G$. affinis $(G a)$. Further, the $\delta^{13} \mathrm{C}$ gradient between G. ruber (white; $\mathrm{Gr}$ ) and $\mathrm{C}$. mabahethi $(\mathrm{Cm})$ of core SO236-052-4 was estimated to assess the sea surface and bottom water stable carbon isotope difference and water column mixing.

\subsection{Spectral analyses}

For the evaluation of periodic temporal variability, Blackman-Tukey spectral analyses were performed for $\mathrm{TOC}, \mathrm{Fe} / \mathrm{Al}$ and $\mathrm{Ti} / \mathrm{Al}$ ratios, $\mathrm{Br} \mathrm{XRF}$ counts of core SO236-052-4, the reconstructed oxygen concentrations of core SO236-052-4 and Arabian Sea core GeoB3004 (Schmiedl and Mackensen, 2006), and the $\Delta$-insolation at $30^{\circ} \mathrm{N}$. The analyses were carried out with the AnalySeries software 2.0 version 05/2005 (Paillard et al., 1996). Prior to the analyses, the records of SO236-052-4 were rescaled with $\Delta t=2 \mathrm{ka}$ (TOC, oxygen) and $\Delta t=0.5 \mathrm{ka}(\mathrm{Fe} / \mathrm{Al}, \mathrm{Ti} / \mathrm{Al}$, $\mathrm{Br}$ XRF counts), and the oxygen record of GeoB3004 was rescaled with $\Delta t=1 \mathrm{ka}$.

\subsection{Radiocarbon dating and compilation of the age model}

Accelerator mass spectrometry (AMS) radiocarbon dating was carried out at the Beta Analytic Radiocarbon Dating Laboratory on mixed surface-dwelling planktonic foraminifera from $35 \mathrm{~cm}, 80 \mathrm{~cm}$ and $140 \mathrm{~cm}$ of depth in core SO236-052-4 (Table 1). Due to the contrasting available reservoir age correction values (varying between 301 and 544 years; Dutta et al., 2001; Southon et al., 2002), the AMS ${ }^{14} \mathrm{C}$ ages were corrected for the global reservoir age of 400 years in order to minimize potential errors and converted to calendar years using the radiocarbon calibration program CALIB (version 7.0.4; Stuiver and Reimer, 1993) and the calibration curve Marine13 (Reimer et al., 2013). Additional age tie points were derived from graphical correlation of the benthic $\delta^{18} \mathrm{O}$ record of core SO236-052-4 with the LR04 standard benthic stack (Lisiecki and Raymo, 2005) using the software AnalySeries 2.0 (version 5/2005; Paillard et al., 1996). The age model of core M74/4-1143 (Betzler et al., 2013b) was revised by graphical correlation with the planktonic $\delta^{18} \mathrm{O}$ record of core SO236-052-4 (Fig. 2).

\section{Results}

\subsection{Age model and sedimentation rate}

Based on the radiocarbon ages and the alignment of the stable oxygen isotope stratigraphy, core SO236-052-4 is comprised of sediments from the past $207.7 \mathrm{kyr}$ (Fig. 2). The top $6 \mathrm{~m}$ of sediment core M74/4-1143 is comprised of the past $242.3 \mathrm{kyr}$. Average sedimentation rates varied between $3.5 \mathrm{~cm} \mathrm{ka}^{-1}$ in SO236-052-4 and $4.4 \mathrm{~cm} \mathrm{ka}^{-1}$ in M74/4-1143. Maximum sedimentation rates occurred during interglacial intervals, with $6.8 \mathrm{~cm} \mathrm{ka}^{-1}$ (SO236-0524) and $8.4 \mathrm{~cm} \mathrm{ka}^{-1}$ (M74/4-1143) for the Eemian and $7.1 \mathrm{~cm} \mathrm{ka}^{-1}$ (SO236-052-4) to $3.0 \mathrm{~cm} \mathrm{ka}^{-1}$ (M74/4-1143) for the Holocene (Fig. 2).

\subsection{Foraminiferal stable oxygen and carbon isotope records}

The $\delta^{18} \mathrm{O}$ values of core SO236-052-4 vary between -3.09 and $-0.68 \%$ in the planktonic G. ruber, between 0.91 and $2.51 \%$ in the epibenthic C. mabahethi, and between 1.10 and $5.02 \%$ in the deep infaunal G. affinis (Fig. 3). Generally, the $\delta^{18} \mathrm{O}$ records reveal a consistent picture with relatively higher values during glacial intervals and lower values during interglacial intervals. The $\delta^{13} \mathrm{C}$ values of core SO236-052-4 vary between 0.12 and $1.25 \%$ in G. ruber, between 0.22 and $0.91 \%$ in C. mabahethi, and between -0.84 and $0.27 \%$ in G. affinis (Fig. 3). Despite considerable short-term variability, all records reveal a stepwise increase in $\delta^{13} \mathrm{C}$ values with lowest values during the Marine Isotope Stage (MIS) 6 and highest values during the Holocene (Fig. 3).

Considering the past bottom water oxygen concentration reconstruction for core $\mathrm{SO} 236-052-4$ by using the $\Delta \delta^{13} \mathrm{C}_{\mathrm{Cm}-\mathrm{Ga}}$ estimation, the $\left[\mathrm{O}_{2}\right]$ values varied between $10.43 \mu \mathrm{mol} \mathrm{kg}{ }^{-1} \quad\left(\hat{=} 0.50 \% 0 \quad \Delta \delta^{13} \mathrm{C}_{\mathrm{Cm}-\mathrm{Ga}}\right)$ and $139.45 \mu \mathrm{mol} \mathrm{kg}^{-1}\left(\hat{=} 1.49 \% \circ \Delta \delta^{13} \mathrm{C}_{C m-G a}\right)$ with average values of approximately $67.10 \mu \mathrm{mol} \mathrm{kg}{ }^{-1}(\hat{=} 0.93 \%$ o $\left.\Delta \delta^{13} \mathrm{C}_{\mathrm{Cm}-\mathrm{G} a}\right)$. In addition, a long-lasting oxygen depletion was observed, starting from the end of MIS 5 to the end of MIS 3 (duration of $\sim 50 \mathrm{kyr}$ ), with average oxygen concentrations of approximately $52.50 \mu \mathrm{mol} \mathrm{kg}{ }^{-1}$. The oxygen concentration of sediment core GeoB3004 (western Arabian Sea) showed an average oxygen content of approximately $81.75 \mu \mathrm{mol} \mathrm{kg}{ }^{-1}\left(\hat{=} 1.05 \% \Delta \Delta \delta^{13} \mathrm{C}_{C w-G a}\right)$, with variations between $22.04 \mu \mathrm{mol} \mathrm{kg}^{-1}\left(\hat{=} 0.58 \% \Delta \Delta \delta^{13} \mathrm{C}_{C w-G a}\right)$ and $133.87 \mu \mathrm{mol} \mathrm{kg}{ }^{-1}\left(\hat{=} 1.45 \% \circ \Delta \delta^{13} \mathrm{C}_{C w-G a}\right.$ ) (Schmiedl and Mackensen, 2006). Spectral analyses of the oxygen records of cores SO236-052-4 and GeoB3004 reveal strong power in the precession band (Fig. 4a). Error estimations at the $95 \%$ confidence level on the power spectrum of the oxygen records are $0.49<\Delta$ Power / Power $<3.06$ (SO236$052-4)$ and $0.49<\Delta$ Power / Power $<3.08$ (GeoB3004). The comparatively long-lasting oxygen depletion during the last 
Table 1. Accelerator mass spectrometry (AMS) radiocarbon dating results based on mixed surface-dwelling planktonic foraminifera $(G r=$ Globigerinoides ruber, white; Gs = Globigerinoides sacculifer) from 35, 80 and $140 \mathrm{~cm}$ of sediment depth in core SO236-052-4. Conventional radiocarbon ages were calibrated using the radiocarbon calibration program CALIB (version 7.0.4; Stuiver and Reimer, 1993) and the calibration curve Marine13 (Reimer et al., 2013).

\begin{tabular}{|c|c|c|c|c|c|c|c|c|c|}
\hline \multirow[t]{2}{*}{ No. } & \multirow[t]{2}{*}{ Sample ID } & \multirow[t]{2}{*}{ Lab ID } & \multirow[t]{2}{*}{ Material } & \multirow[t]{2}{*}{$\begin{array}{r}\text { Core depth } \\
\text { [m b.s.f.] }\end{array}$} & \multirow[t]{2}{*}{$\begin{array}{r}{ }^{12} \mathrm{C} /{ }^{13} \mathrm{C} \\
\text { o/oo }\end{array}$} & \multirow[t]{2}{*}{$\begin{array}{l}{ }^{14} \mathrm{C} \text { age } \\
\text { ya BP }\end{array}$} & \multicolumn{3}{|c|}{$\begin{array}{c}\text { Calibrated age }(\Delta R 0) \\
\text { cal BP }(2 \mathrm{~s} \text { ranges, } 95.4 \% \text { probability })\end{array}$} \\
\hline & & & & & & & $\begin{array}{r}\text { range } \\
\text { [years] }\end{array}$ & $\begin{array}{l}\text { rel. area } \\
\text { u. distr. }\end{array}$ & $\begin{array}{l}\text { median of } \\
\text { prob. }[\mathrm{ka}]\end{array}$ \\
\hline 1 & SO236-052-035 & Beta-418574 & $G r, G s$ & 0.35 & +1.4 & $7940 \pm 30$ & 8330-8480 & 1.00 & $8.4 \pm 0.08$ \\
\hline 2 & SO236-052-080 & Beta-418575 & $G r, G s$ & 0.80 & +1.6 & $12890 \pm 40$ & $14310-15020$ & 1.00 & $14.7 \pm 0.36$ \\
\hline 3 & SO236-052-140 & Beta-418576 & $G r, G s$ & 1.40 & +1.8 & $23930 \pm 100$ & $27480-27850$ & 1.00 & $27.7 \pm 0.19$ \\
\hline
\end{tabular}

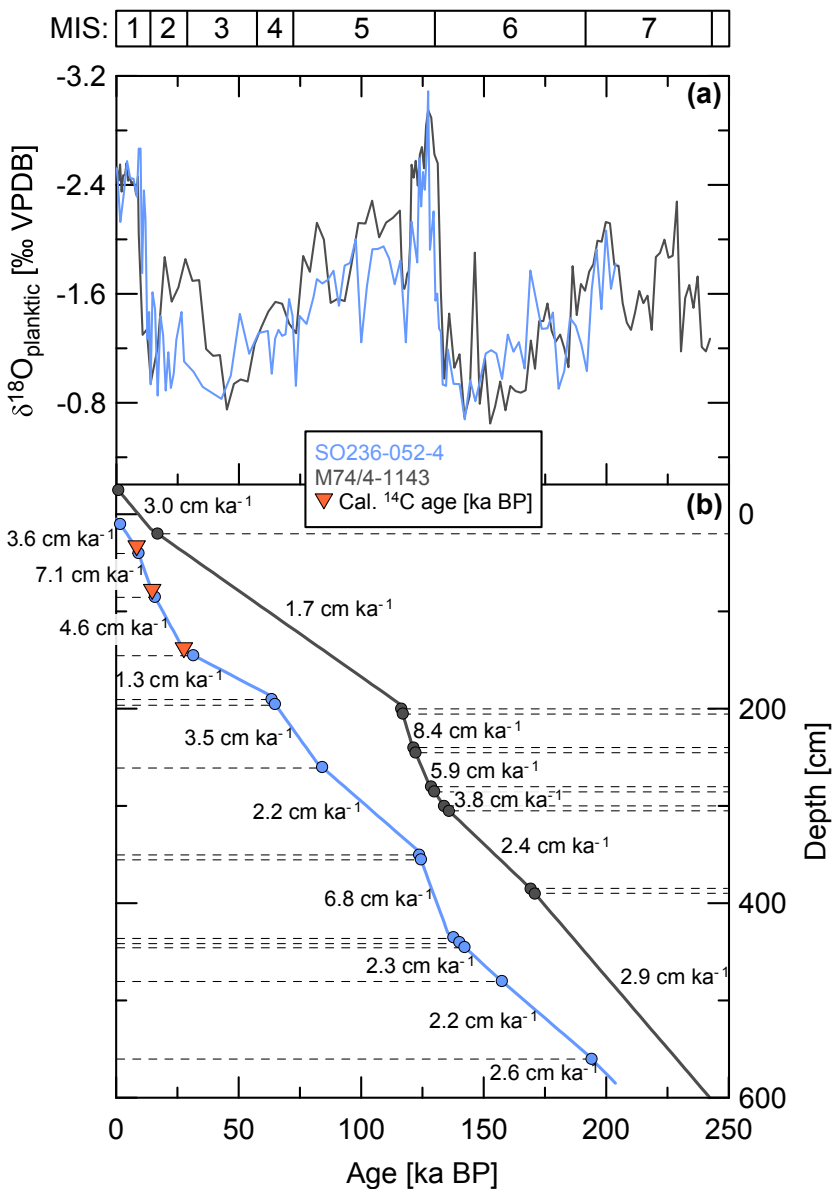

Figure 2. Full-resolution stable oxygen isotope records of the planktonic foraminifer $G$. ruber (a) and age-depth plots for the sediment cores SO236-052-4 (light blue) and M74/4-1143 (grey). Orange triangles indicate radiocarbon dates and circles indicate age control points derived from correlation with the LR04 benthic isotope stack of Lisiecki and Raymo (2005). Sedimentation rates are derived from linear interpolation between age data. MIS denotes the marine stable oxygen isotope stages. glacial period at site $\mathrm{SO} 236-052$ is not observed at site GeoB3004.

The $\Delta \delta^{13} \mathrm{C}_{G r-C m}$ calculation for site SO236-052 showed maximum differences in the planktonic and epibenthic stable $\delta^{13} \mathrm{C}$ values $(0.68 \%$ o) during the full interglacial periods of MIS 7, 5 and 1, coinciding with global sea-level highstands. Accordingly, minimum differences $(-0.54 \%$ ) were documented for the glacial periods MIS 6 and 2 and sea-level lowstands.

\subsection{Sedimentological and geochemical records}

The detailed sedimentological and geochemical data of core SO236-052-4 reveal a glacial-interglacial pattern but also considerable short-term variability (Figs. 4c-f, 5). Sortable silt records are available for both sites and in general they show coarser means during interglacial times, up to $14 \mu \mathrm{m}$ during the Holocene and $>13 \mu \mathrm{m}$ during the Eemian (Figs. 5a, 6). However, absolute values and variability are much greater in core M74/4-1143, which is located in the drift of the Kardiva Channel (see Betzler et al., 2013b) compared to core SO236-052-4 from the more sheltered part of the Inner Sea. In core M74/4-1143, sortable silt shows an increase towards the MIS 6-5 transition (Termination II) followed by generally elevated values during the Eemian (maximum $27.17 \mu \mathrm{m}$ ), whereas there is much less variability at the same time in the data from core SO236-052-4. Both cores show a coarsening of the sortable silt towards the MIS 1.

Bulk mean grain size shows a pronounced glacialinterglacial variability of up to $57 \mu \mathrm{m}$ during the MIS 2 and MIS 6 and values between 10 and $30 \mu \mathrm{m}$ for the remainder (Fig. 5a). The finest sediments occur during the early MIS 5 and the MIS $1(10 \mu \mathrm{m})$.

The total organic carbon (TOC) and calcium carbonate $\left(\mathrm{CaCO}_{3}\right)$ contents of core SO236-052-4 reveal reverse glacial-interglacial trends with maximum TOC content during glacial and maximum carbonate contents during interglacial periods. TOC varies between $0.85 \mathrm{wt} \%$ (interglacial) and $2.06 \mathrm{wt} \%$ (glacial), whereas the carbonate content varies between $77.03 \mathrm{wt} \%$ (glacial) and $89.40 \mathrm{wt} \%$ (interglacial) (Fig. 5b). 

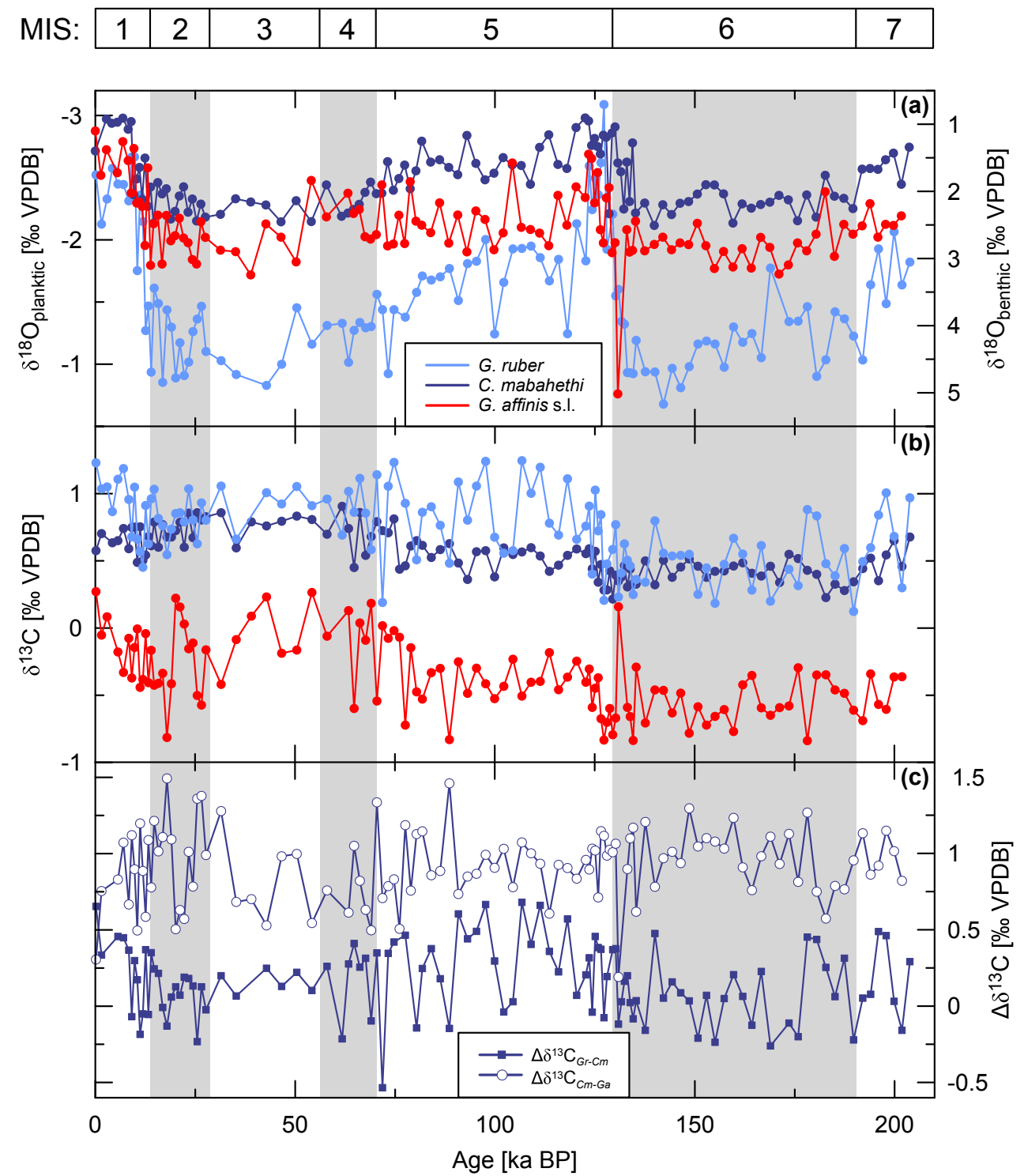

Figure 3. (a, b) Stable oxygen and carbon isotope records of planktonic and benthic foraminifera in sediment core SO236-052-4. Displayed are the planktonic species G. ruber (light blue), the epibenthic species $C$. mabahethi (dark blue) and the deep infaunal species $G$. affinis s.l. (red). Also shown are the full-resolution data of the $\Delta \delta^{13} \mathrm{C}_{G r-C m}$ and $\Delta \delta^{13} \mathrm{C}_{C m \text {-Ga }}$ signals (c) as a result of the difference between the $\Delta \delta{ }^{13} \mathrm{C}$ values of $G$. ruber and C. mabahethi, as well as $C$. mabahethi and G. affinis s.l. MIS denotes the marine stable oxygen isotope stages.

Both the $\mathrm{Fe} / \mathrm{Al}$ and $\mathrm{Ti} / \mathrm{Al}$ records show similar patterns with relatively higher values during glacial periods and slightly increasing values towards today. The Br XRF counts and the $\mathrm{Si} / \mathrm{Ca}$ ratio show similarly distinct glacialinterglacial patterns comparable to the TOC record, with generally higher values during glacial periods and lower values during interglacial periods (Fig. 5d). Further, the $\mathrm{Si} / \mathrm{Ca}$ record is characterized by an abrupt and short-lasting maximum at Termination II (Fig. 5d). Inverse patterns are observed for the $\mathrm{Sr} / \mathrm{Ca}$ record, which follows the inversed $\delta^{18} \mathrm{O}$ curve and shows higher values during interglacial and lower values during glacial periods (Fig. 5d).
Spectral analyses of TOC, $\mathrm{Ti} / \mathrm{Al}$ and $\mathrm{Br}$ reveal substantial but considerably weaker variability in the precession band when compared to the reconstructed oxygen records (Fig. 4c, e). The $\mathrm{Fe} / \mathrm{Al}$ record lacks substantial precessional variability but is rather dominated by long-term glacial-interglacial changes (Fig. 4e). Error estimation at the $95 \%$ confidence level on the power spectra of $\mathrm{TOC}, \mathrm{Fe} / \mathrm{Al}, \mathrm{Ti} / \mathrm{Al}$ and $\mathrm{Br}$ is $0.49<\Delta$ Power / Power $<3.09$. 

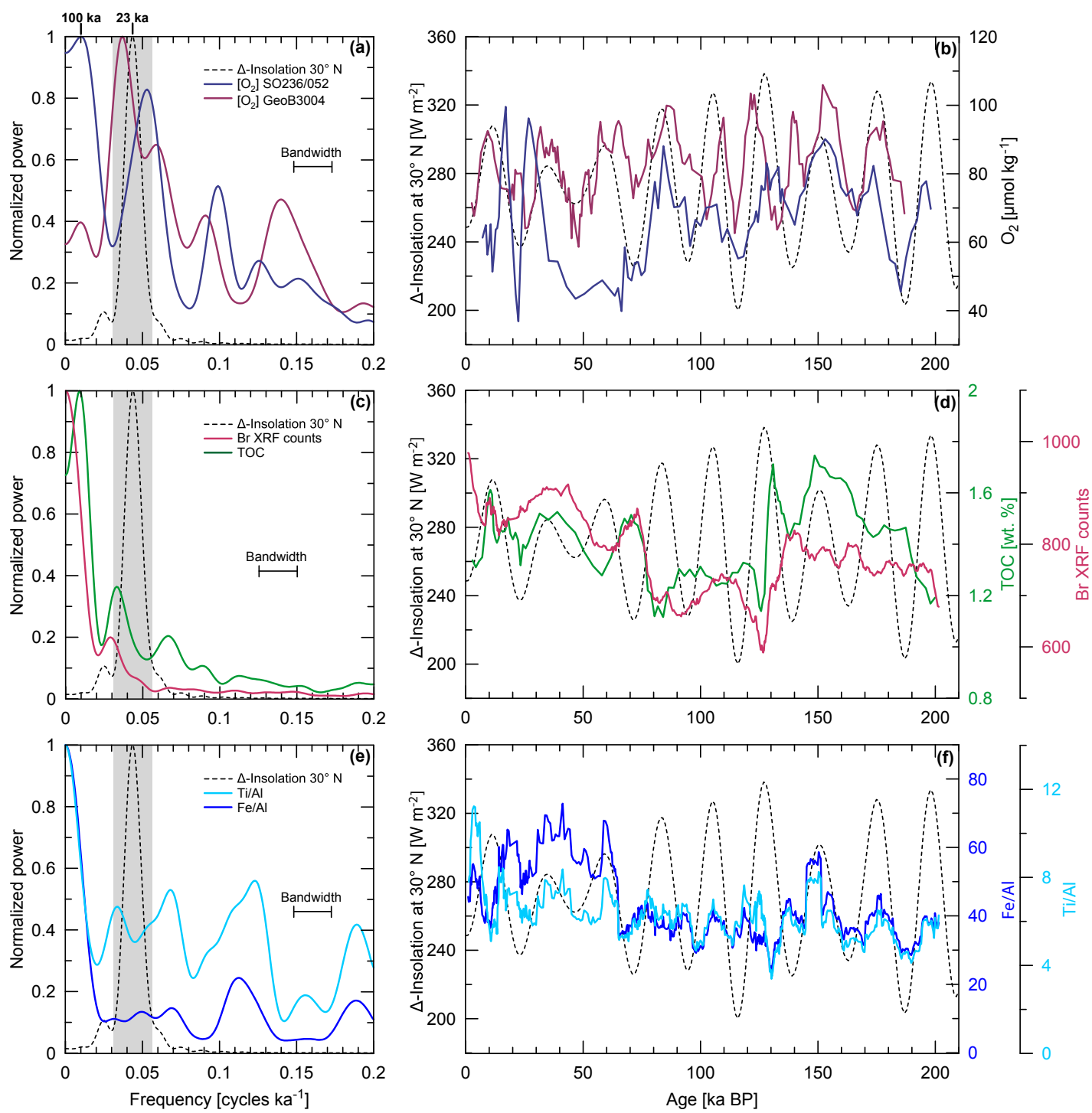

Figure 4. Records and normalized Blackman-Tukey power spectra of (a, b) the oxygen reconstructions of core SO236-052-4 (blue) and GeoB3004 (purple), (c, d) productivity proxies TOC (green) and Br XRF counts (pink), and (e, f) dust proxies Ti / Al (light blue) and Fe / Al (dark blue) in comparison to the $\Delta$-insolation at $30^{\circ} \mathrm{N}$ (black dashed line). Grey bars indicate the 23 kyr period of the $\Delta$-insolation and its bandwidth. Oxygen and TOC records represent 5-point running averages; Br XRF counts and Ti / $\mathrm{Al}$ and Fe / $\mathrm{Al}$ records represent 15-point running averages.

\subsection{Benthic foraminiferal record}

In sediment core SO236-052-4, a total of 256 different benthic foraminiferal species were distinguished, with 51 to 93 different species per sample. The diversity $H(S)$ is relatively high and varies between 3.3 and 4.0, with a slight long-term decrease towards today (Fig. 7a). The foraminiferal fauna at the Inner Sea is dominated by hyaline taxa. In comparison, agglutinated individuals were less abundant, but with increasing relative abundances up to approximately $\geq 20 \%$ of the entire fauna during the glacial periods (Fig. 8e). The three-component model of the Q-mode PCA explains $89.14 \%$ of the total variance (Table 2). Assem- blage 1 (PC1) explains $31.54 \%$ of the total variance and is dominated by Neouvigerina proboscidea and Discorbinella araucana, with Hyalinea inflata, Cymbaloporetta squammosa, Bulimina marginata and Rosalina vilardeboana as associated taxa (Table 2). This assemblage occurred mainly during the late MIS 7 and 5 and is less pronounced during MIS 4 to early MIS 2 (Fig. 7b). Assemblage 2 (PC2) explains $30.54 \%$ of the total variance and is dominated by Cibicides mabahethi, with Discorbinella bertheloti, Siphogenerina columellaris, Gyroidina umbonata, Reophax sp., H. inflata and D. araucana as associated taxa (Table 2). Assemblage 2 occurred mainly during MIS 6 and 1 (Fig. 7c). 

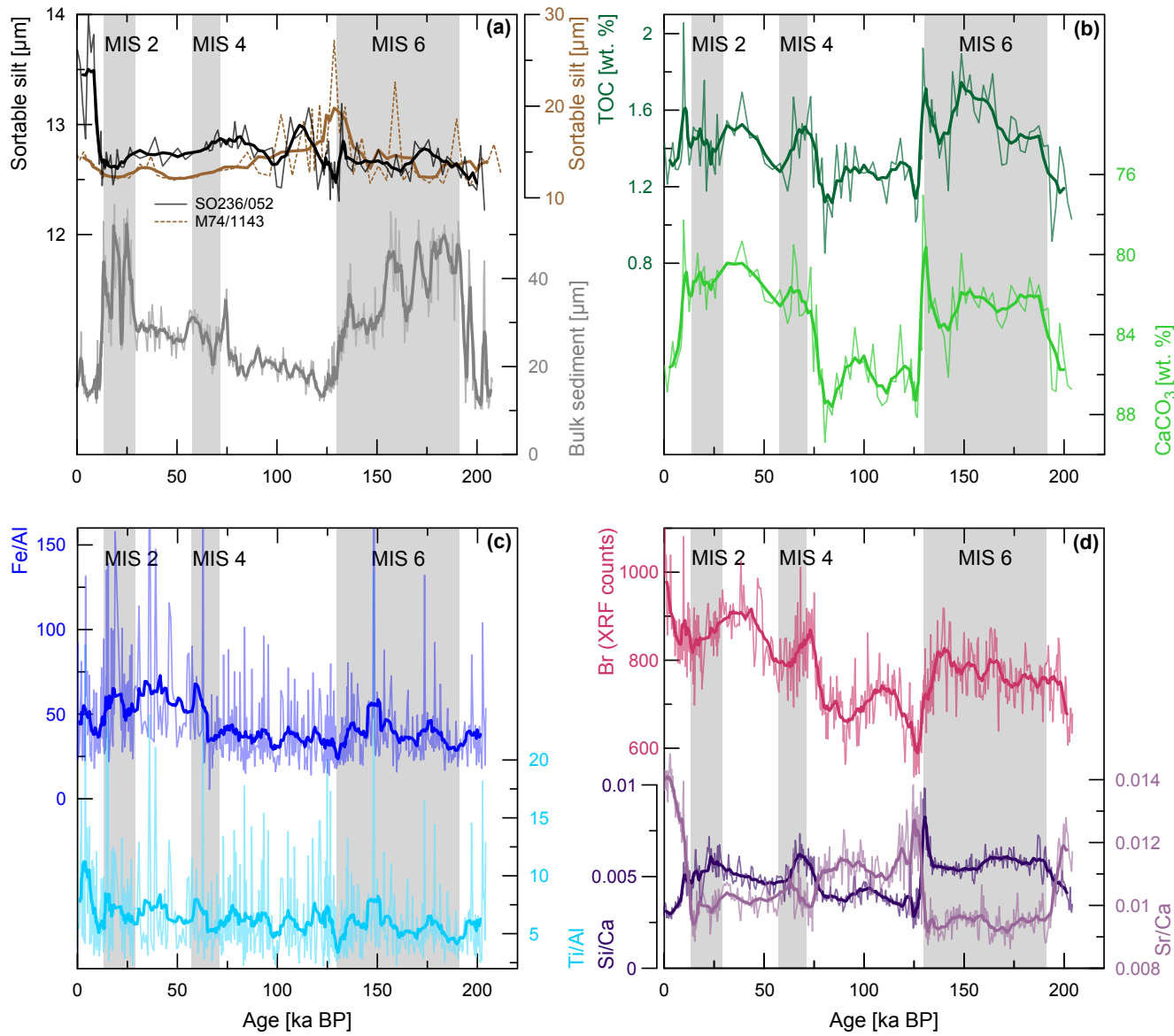

Figure 5. Sedimentological and geochemical records of sediment core SO236-052-4 from the central part of the Maldives Inner Sea. (a) Sortable silt (black) in comparison with the data of core M74/4-1143 (brown) and bulk sediment (grey) mean values, (b) total organic carbon (TOC) (dark green) and calcium carbonate (light green) content of the sediment, (c) iron (dark blue) and titanium (light blue) in relation to the aluminium XRF counts and (d) bromine XRF counts (pink), and silicon (dark purple) and strontium (light purple) in relation to the calcium XRF counts. Thin lines represent full-resolution data, bold lines in panels (a) and (b) indicate 5-point running averages, whereas all XRF counts in panels (c) and (d) are displayed as 15-point running averages (bold lines). MIS denotes the marine stable oxygen isotope stages.

Assemblage 3 (PC3) explains $27.06 \%$ of the total variance and is dominated by $N$. proboscidea and Hoeglundina elegans, with D. bertheloti, Cibicidoides subhaidingeri, Discorbis sp., Spiroplectinella sagittula s.1. and C. mabahethi as associated taxa (Table 2). Assemblage 3 occurred during MIS 4 to 2 (Fig. 7d). The distribution of the most important benthic foraminiferal species, which characterize the three faunal assemblages, is displayed in Fig. 7e-g. The most abundant species include $C$. mabahethi (maximum relative abundance of $\sim 17 \%$ during MIS 6 ), the weakly hispid $N$. proboscidea (maximum of $\sim 16 \%$ at the end of MIS 5) and D. araucana (maximum of $\sim 11 \%$ during the onset of MIS 5). Meroplanktonic benthic foraminifera (genera Cymbaloporetta and Tretomphaloides) occurred in elevated numbers during interglacial periods (maximum of $10.88 \%$ ), particularly during MIS 5 (Figs. 6d, 7e).

\section{Discussion}

\subsection{Dust fluxes, marine productivity and monsoon variability}

The $\mathrm{Ti} / \mathrm{Al}$ and $\mathrm{Fe} / \mathrm{Al}$ in core SO236-052-4 were used as proxies for terrigenous sediment delivery, reflecting changes in the deposition of aeolian dust and thus in the aridity of the hinterland as the source area of the dust (Zhang et al., 1993; Lourens et al., 2001; Itambi et al., 2009). Local sources of Fe-rich sediments can be excluded since the sediments of the Maldives archipelago and adjacent shallow- to deep-water environments are characterized by carbonates comprised of reef and lagoon carbonates of the islands and pelagic deepwater carbonates (Betzler et al., 2013b; Reolid et al., 2017). This is also reflected by the calcium carbonate content, which is very high at site SO236-052 throughout the past $200 \mathrm{kyr}$ (Fig. 5b). Studies on modern aerosols in the North Pacific re- 


MIS: \begin{tabular}{|l|l|l|l|l|l|l|l|}
\hline & 2 & 3 & 4 & 5 & 6 & 7 & \\
\hline
\end{tabular}

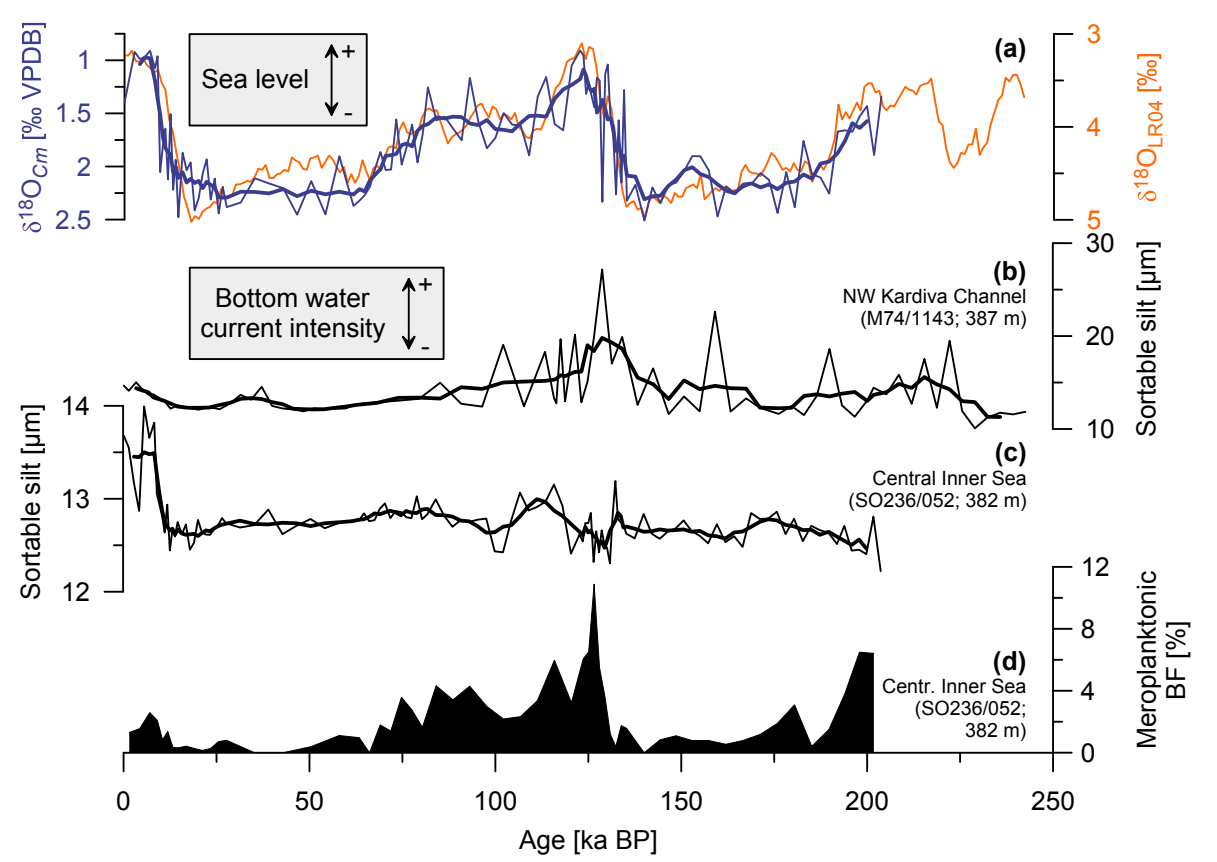

Figure 6. (a) Epibenthic stable oxygen isotope record of core SO236-052-4 (dark blue) in comparison with the LR04 benthic stable isotope stack (orange; Lisiecki and Raymo, 2005). (b, c) Comparison of the sortable silt records of sediment cores M74/4-1143 and SO236-052-4 and (d) relative abundance of meroplanktonic benthic foraminifera (BF; including the genera Cymbaloporetta and Tretomphaloides) in sediments of core SO236-052-4. Thin lines represent full-resolution data, bold lines indicate 5-point running averages. MIS denotes the marine stable oxygen isotope stages.

Table 2. Species composition of benthic foraminiferal assemblages. Principal component number, dominant (bold) and important associated species with principal component scores (Q-mode) and explained variance in percent of total variance are given.

\begin{tabular}{llrr}
\hline $\begin{array}{l}\text { Q-mode principal } \\
\text { components }\end{array}$ & Species & Scores & $\begin{array}{r}\text { Explained } \\
\text { variance [\%] }\end{array}$ \\
\hline PC1 & Neouvigerina proboscidea & 5.812 & 31.54 \\
& Discorbinella araucana & 3.948 & \\
& Hyalinea inflata & 2.562 & \\
& Cymbaloporetta squammosa & 1.913 & \\
& Bulimina marginata & 1.729 & \\
& Rosalina vilardeboana & 1.595 & \\
& Cibicides mabahethi & 7.466 & 30.54 \\
& Discorbinella bertheloti & 1.756 & \\
& Siphogenerina columellaris & 1.622 & \\
& Gyroidina umbonata & 1.589 & \\
& Reophax sp. & 1.387 & \\
& Hyalinea inflata & 1.214 & \\
& Discorbinella araucana & 1.109 & \\
& Neouvigerina proboscidea & 4.608 & \\
& Hoeglundina elegans & 3.952 & \\
& Discorbinella bertheloti & 3.004 & \\
& Cibicidoides subhaidingeri & 2.311 & \\
& Discorbis sp. & 2.161 & \\
& Spiroplectinella sagittula s.1. & 1,808 & \\
& Cibicides mabahethi & 1,084 & \\
& & & \\
& &
\end{tabular}

gion indicate that most of the oceanic iron input is derived from atmospheric transport after mobilization from the central Asian deserts and Chinese loess plateau (Duce and Tindale, 1991). Accordingly, the most likely dust sources for the observed $\mathrm{Fe}$ in the sediments of the Maldives are the Indian subcontinent and the Asian desert and loess areas (Roberts et al., 2011), although a minor contribution from north-eastern Africa and Arabia cannot be excluded (Chauhan and Shukla, 2016). The latter regions rather have been identified as major dust sources in the Arabian Sea based on specific clay mineral composition and the magnetic susceptibility of the lithogenic fraction (deMenocal et al., 1991; Sirocko and Lange, 1991). North-west winds over the Arabian Peninsula blow dust into the Arabian Sea when the Arabian source areas undergo aridification during high-latitude ice cover (deMenocal et al., 1991; Sirocko and Lange, 1991). In the northwestern Arabian Sea, associated dust fluxes are in phase with maximum ice volume but also vary in the precessional band, suggesting a likewise strengthening of the SW summer monsoon as an important regional driver (Clemens and Prell, 1990; Clemens et al., 1996). In contrast, in the eastern equatorial Indian Ocean the majority of dust is transported via the NE monsoon, coinciding with the prevailing wind system, which blows during Northern Hemisphere winter. Therefore, elevated $\mathrm{Fe} / \mathrm{Al}$ and $\mathrm{Ti} / \mathrm{Al}$ ratios at site $\mathrm{SO} 236-052$ indicate 


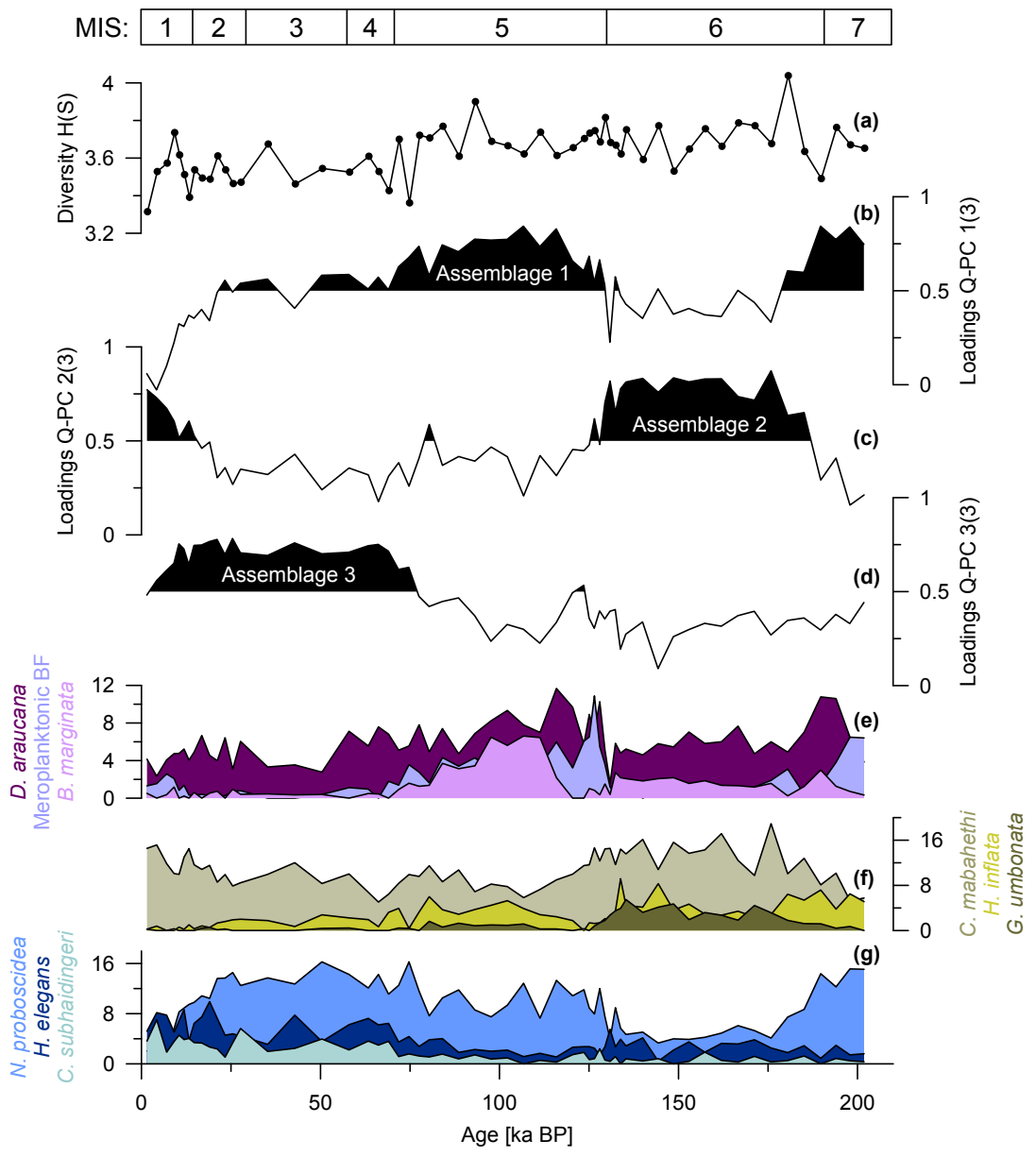

Figure 7. Comparison of benthic foraminiferal faunal records of core SO236-052-4 from the central part of the Maldives Inner Sea. (a) Shannon-Wiener diversity index $H(S)$, (b-d) Q-mode benthic foraminiferal assemblages, including the $N$. proboscidea and D. araucana fauna (assemblage 1), the $C$. mabahethi fauna (assemblage 2), and the $N$. proboscidea and H. elegans fauna (assemblage 3 ). Loadings $\geq 0.5$ are defined as significant after Backhaus et al. (2008). (e-g) Distribution of selected important and associated benthic foraminiferal taxa, given in percent. The meroplanktonic benthic foraminifera (BF) are comprised of the genera Cymbaloporetta and Tretomphaloides.

the combined effects of enhanced glacial dust availability in the source areas and dust transport to the Maldives with generally strengthened NE monsoon winds during the glacial intervals of MIS 6 and MIS 4-2. On a global scale, the generally colder and drier glacial conditions resulted in a twofold to fivefold increase in dust fluxes (Maher et al., 2010).

The observed response of the winter circulation in the Maldives to glacial conditions is in line with the finding of a general strengthening of the NE Indian monsoon after the initiation of the Northern Hemisphere glaciation (Gupta and Thomas, 2003). But our dust proxies show little (Ti / Al) to no $(\mathrm{Fe} / \mathrm{Al})$ variability at the precessional band (Fig. 4e), which should be expected if the dust fluxes were directly proportional to the intensity of the winter monsoon (Caley et al., 2011a, b). For a statistically more robust evaluation of the full orbital variability (including the long-wave components) considerably longer time series would be required. Nevertheless, graphical comparison of our data series reveals a dominant eccentricity component in the dust proxies with pronounced glacial-to-interglacial changes, suggesting a link to high-latitude climate and environmental changes (Fig. 8). Therefore the dust records of the Maldives Inner Sea are mainly driven by the generally enhanced dust availability during glacial intervals. As a major dust source, the Chinese loess plateau is strongly influenced by the East Asian monsoon (EAM). During the Late Quaternary, EAM and related vegetation changes are characterized by predominant eccentricity cycles associated with the advance and retreat of the boreal ice sheets (Ding et al., 1995; Liu et al., 1999; Sun et al., 2006; Hao et al., 2012). Our conclusion is also in line with the lithogenic flux reconstructions from the Arabian Sea (e.g. site ODP722; Clemens et al., 1996), which show striking changes on the glacial-to-interglacial timescale (in the eccentricity band) and suggest a close relation between highlatitude climate and the aridity of the dust source areas. On the Chinese loess plateau, the onset of glacial conditions led 


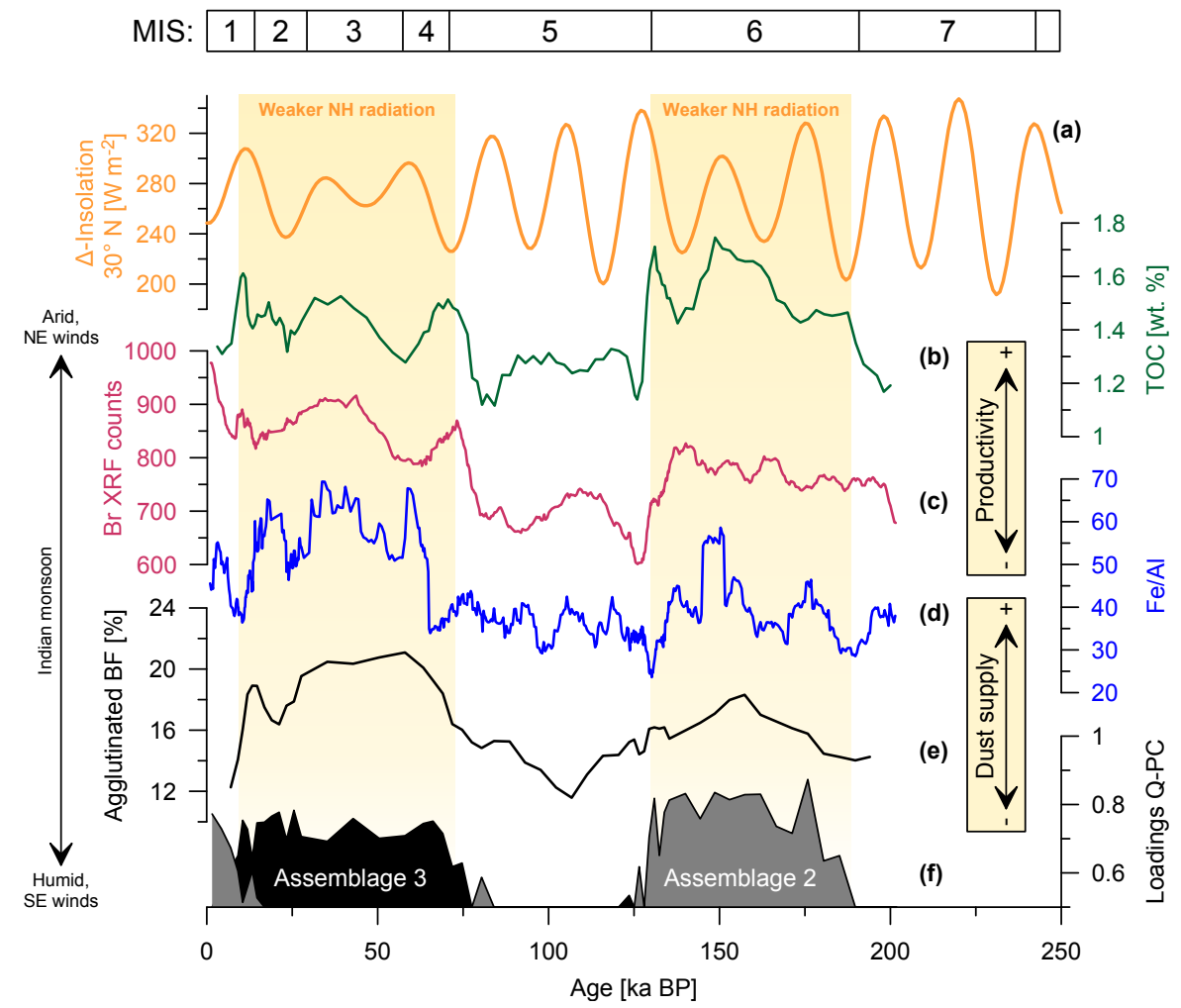

Figure 8. Variation in the insolation difference between the June and December solstice at $30^{\circ} \mathrm{N}$ (after Laskar et al., 2004; calculated with AnalySeries 2.0: Paillard et al., 1996) (a) in graphical correlation with geochemical and benthic foraminiferal productivity records of core SO236-052-4. (b) Total organic carbon (TOC) content and (c) bromine as derived from XRF scanning count data as a tracer for marine organic carbon (MOC), (d) Fe / Al ratio and (e) relative abundance of agglutinated benthic foraminifera as an indicator for enhanced dust supply. (f) Principal components (PCs) show the C. mabahethi fauna (assemblage 2) and N. proboscidea and H. elegans fauna (assemblage 3). This comparison reveals coherent glacial-to-interglacial changes in all proxy records with elevated values during glacial stages MIS 6 and MIS 4 2 and during a weaker Northern Hemisphere solar radiation amplitude (yellow bars). Thin lines represent full-resolution data, bold lines in panels (b) and (e) indicate 5-point running averages and bold lines in panels (c) and (d) indicate a 15-point running average. MIS denotes the marine stable oxygen isotope stages.

to an abrupt increase in atmospheric dust loadings (Zhang et al., 2002), suggesting the operation of climate-vegetation feedbacks. Enhanced deposition of terrestrial particles at site SO236-052 led to a general coarsening of the glacial sediment and fostered the distribution of agglutinated benthic foraminifera, which reached a relative abundance of up to $\sim 20 \%$ during the last glacial period (Figs. 5, 8e). Most agglutinated foraminifera in core SO236-052-4 belong to the Textulariida, such as Spiroplectammina sagittula, Textularia calva and Textularia pala. These and related taxa are often associated with relatively coarse-grained substrates and they preferentially use siliciclastic grains for building up their test walls (Allen et al., 1999; Murray, 2006; Armynot du Châtelet et al., 2013).

The modern equatorial Indian Ocean is limited in the micronutrient iron (Wiggert et al., 2006; Maher et al., 2010), and therefore enhanced aeolian $\mathrm{Fe}$ fluxes to the ocean during glacial periods likely have a direct impact on the seasonal surface productivity (Martin et al., 1991; Boyd et al., 2000;
Gao et al., 2001; Jickells et al., 2005), which also influences the deep-sea benthic ecosystems through seasonal phytodetritus pulses. Similar relations between Fe fluxes and surface ocean productivity have been reported from the Southern Ocean (Anderson et al., 2014; Martínez-García et al., 2014) and the equatorial Pacific Ocean (Costa et al., 2016). The TOC and $\mathrm{Br}$ contents of marine sediments are widely used as proxies for organic matter fluxes and surface water productivity (Müller and Suess, 1979; Rühlemann et al., 1999; Ziegler et al., 2008, 2009; Caley et al., 2013). But the applicability of both proxies in quantitative reconstructions is limited by the specific sedimentological and biogeochemical processes at the sediment-water interface, including the bulk accumulation rate and bottom water oxygenation (Möbius et al., 2011; Schoepfer et al., 2015; Naik et al., 2017). However, elevated TOC and $\mathrm{Br}$ values in core $\mathrm{SO} 236-052-4$ suggest generally enhanced organic matter fluxes during glacial periods, which may reflect the influence of $\mathrm{Fe}$ fertilization (Fig. 8b-d). 
The benthic foraminiferal fauna at site SO236-052 reveal a marked glacial-interglacial pattern (Figs. 7, 8f). The diversity, microhabitat partitioning and species composition of deep-sea benthic foraminiferal faunas are mainly controlled by the combined influences of the quantity and quality of food supply and oxygen content of the bottom and pore waters (Jorissen et al., 1995; Fontanier et al., 2002). The diversity of the fauna is high, with $H(S)$ values always $>3.2$ throughout the studied time interval, suggesting the absence of extreme environmental conditions at the sea floor of the study site. Therefore, the observed faunal changes likely reflect variations in the amount and quality of food supply. The most abundant species of the three benthic foraminiferal assemblages are $C$. mabahethi, $N$. proboscidea and D. araucana, all with PC scores $>3$ in at least one assemblage (Table 2). Microhabitat studies demonstrated that most species of the genera Cibicides and Cibicidoides live as suspension feeders on or elevated above the sea floor (Lutze and Thiel, 1989; Linke and Lutze, 1993); therefore we assume a similar microhabitat preference for $C$. mabahethi. In the Red Sea, this species is adapted to relatively high oxygen contents and low organic matter fluxes (Edelman-Furstenberg et al., 2001; Badawi et al., 2005). The cosmopolitan N. proboscidea inhabits an epifaunal to very shallow infaunal microhabitat (Fontanier et al., 2002; Licari et al., 2003) and has been described as a detritus feeder from various bathyal and abyssal environments. In the South Atlantic Ocean, N. proboscidea is associated with well-ventilated and oligotrophic conditions (Schmiedl et al., 1997). This species thrives under moderate to high organic matter fluxes and oxygen-depleted intermediate waters in the Indian Ocean (Murgese and De Deckker, 2007; De and Gupta, 2010) and was used as a proxy for the strength of the SW monsoon (Gupta and Srinivasan, 1992; Gupta and Thomas, 2003; Sarkar and Gupta, 2014). These observations and the high relative abundance of $N$. proboscidea in core SO236-052-4 during the last glacial intervals MIS 4-2 and the interglacial interval MIS 5 suggest an adaptation to a wide range of trophic conditions and confirms its tolerance to moderate oxygen depletion. Little information is available on the ecology of D. araucana, but its flat trochospiral test morphology and its distribution in the North Atlantic Ocean suggest an epifaunal microhabitat and adaptation to suspended food sources (Corliss and Chen, 1988; Koho et al., 2008). Similar to the closely related D. bertheloti, it may prefer oxic conditions (Duleba et al., 1999; Smith and Gallagher, 2003), with a tolerance for moderate oxygen depletion (Edelmann-Furstenberg et al., 2001). The shallow infaunal Hoeglundina elegans, which mainly occurs together with $N$. proboscidea in assemblage 3 during MIS 4-2, is commonly associated with low to moderate organic matter fluxes, fresh phytodetritus and high oxygen contents (Corliss, 1985; Koho et al., 2008).

The ecological preferences of the dominant taxa suggest that faunal changes at site SO236-052, although pronounced, were driven by rather subtle changes in the amount of organic matter fluxes. Instead, the faunal changes likely reflect variations in the lateral suspension of food particles, the substratespecific development of infaunal niches and the influence of oxygen changes on the quality of the organic matter. The high dominance of the detritus feeders $N$. proboscidea and $H$. elegans in assemblage 3 reflects the highest organic matter fluxes during the last glacial MIS 4-2 (Fig. 8f). In contrast, the dominance of the epifaunal suspension feeder $C$. mabahethi in assemblage 2 during the penultimate glacial (MIS 6) suggests relatively lower organic matter fluxes. The $N$. proboscidea and D. araucana assemblage 1 of MIS 5 reveals some similarity to assemblage 3 , but the high abundance of $D$. araucana suggests an overall lower food flux with a considerable amount of suspended particles. In addition, the relatively finer-grained substrate likely opened infaunal niches as indicated by the presence of the shallow to deep infaunal Bulimina marginata during the MIS 5 (Jorissen and Wittling, 1999) (Fig. 7e). Contrasts in the boundary conditions between different glacials and interglacials may account for the inconsistent association of certain assemblages to either glacial or interglacial periods. For instance, glacial boundary conditions during MIS 6 were different from MIS 4-2, in which the latter was characterized by a relatively higher global ice volume, a related lower sea level (Rohling et al., 2009) and pronounced millennial-scale variability (Dansgaard et al., 1993). Previous studies showed similar patterns, with certain benthic foraminiferal assemblages occurring during both glacial and interglacial periods, e.g. in the Red Sea (Badawi et al., 2005). At the Maldives Inner Sea, glacial-to-interglacial changes in food fluxes were likely not extreme and therefore ecological thresholds for certain species and faunas may not have always been passed during glacial-interglacial transitions. A detailed inspection of assemblage 2 (C. mabahethi fauna) actually displays faunal differences between their occurrences in MIS 1 and MIS 6, although C. mabahethi is the dominant taxon in both intervals.

While the benthic foraminiferal fauna basically varies on the glacial-interglacial timescale, the TOC, $\mathrm{Br}$ and $\mathrm{Ti} / \mathrm{Al}$ records reveal additional variability in the precessional band (Fig. 4). This suggests that marine environmental conditions in the Maldives are linked to high-latitude climate variability and regional monsoonal changes. The surface water productivity of the northern Indian Ocean is driven by windinduced mixing of the upper water column and upwelling of nutrient-rich subsurface waters and thus reveals a close association with seasonal changes in the monsoonal wind system (Nair et al., 1989). Accordingly, productivity changes in the northern and north-western Arabian Sea are coherent with the strength of the SW monsoon (Ivanova et al., 2003; Leuschner and Sirocko, 2003; Singh et al., 2011) and along the Indian western coast with the strength of the NE monsoon (Rostek et al., 1997; Singh et al., 2011). The elevated TOC and $\mathrm{Br}$ values at site SO236-052 during phases of reduced Northern Hemisphere summer insolation suggest a di- 

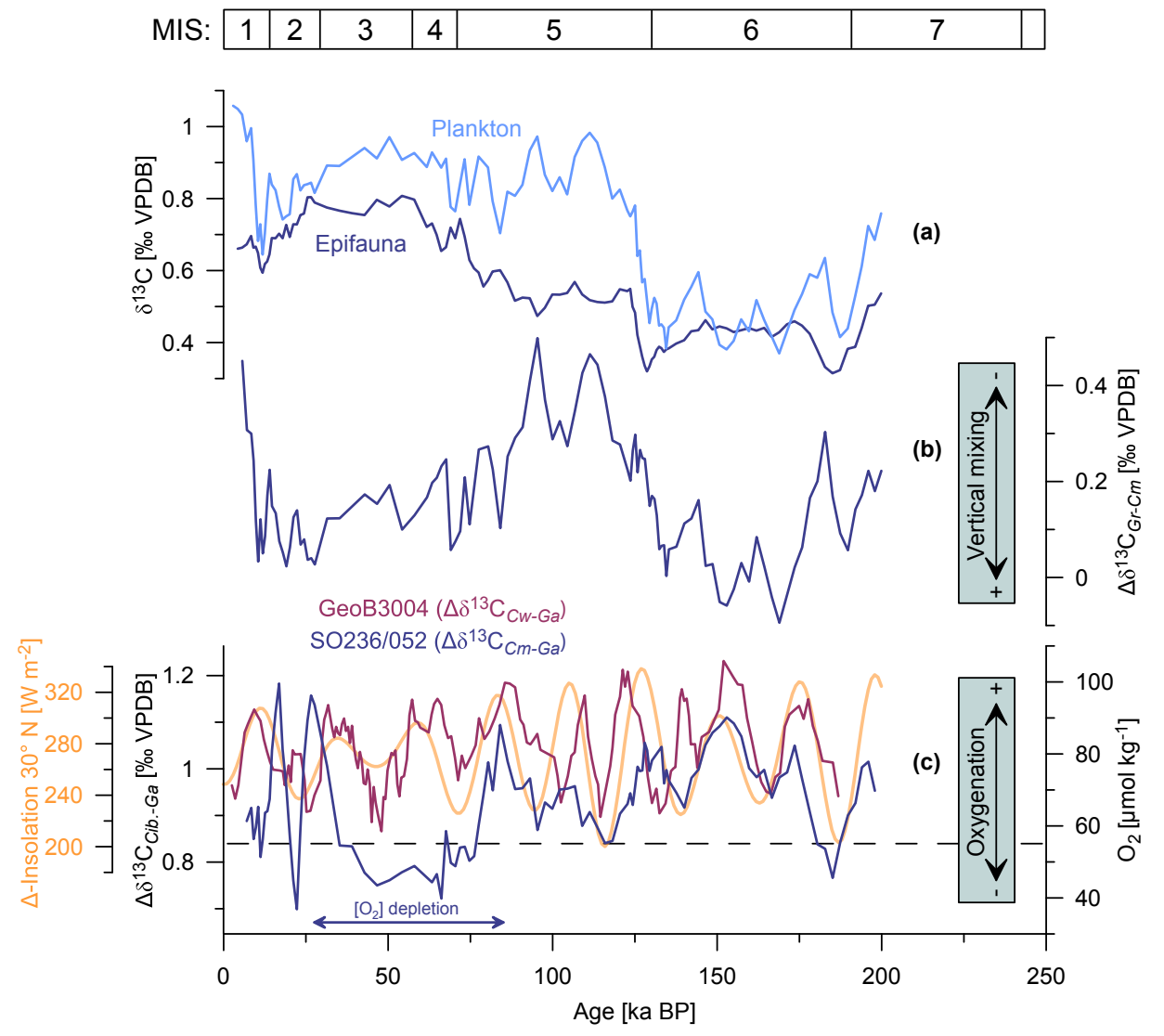

Figure 9. Water mass circulation changes obtained from the stable $\delta^{13} \mathrm{C}$ data of core SO236-052-4 (Indian Ocean) in comparison to ventilation changes in the Arabian Sea; (a) $\delta^{13} \mathrm{C}$ records of the planktonic G. ruber (light blue) and the epibenthic C. mabahethi (dark blue), (b) difference between the planktonic and epibenthic stable carbon records $\left(\Delta \delta^{13} \mathrm{C}_{G r-C m}\right)$ and (c) differences between epibenthic and deep endobenthic $\delta^{13} \mathrm{C}$ records of SO236-052-4 (dark blue) from the intermediate Maldives Inner Sea in comparison to those of GeoB3004 (purple) from the deep Arabian Sea (Schmiedl and Mackensen, 2006). Changes in intermediate- and deep-water oxygen concentrations are calculated by the linear regression between $\Delta \delta^{13} \mathrm{C}$ and $\left[\mathrm{O}_{2}\right]<235 \mu \mathrm{mol} \mathrm{kg}{ }^{-1}$ after Hoogakker et al. (2015). The minimum significance level of $\left[\mathrm{O}_{2}\right]=55 \mu \mathrm{mol} \mathrm{kg}^{-1}$ is shown as a dashed line (Hoogakker et al., 2015). Variation in the insolation difference between the June and December solstice at $30^{\circ} \mathrm{N}$ (yellow) was estimated after Laskar et al. (2004) with AnalySeries 2.0 (Paillard et al., 1996). All lines indicate 5-point running averages. MIS denotes the marine stable oxygen isotope stages. Cib. is Cibicides, Cm is Cibicides mabahethi, Cw is Cibicides wuellerstorfi, Ga is Globobulimina affinis, $\mathrm{Gr}$ is Globigerinoides ruber.

rect influence of the Indian winter monsoon on productivity and related organic matter fluxes of the Maldives Inner Sea during the past $200 \mathrm{kyr}$ (Fig. 8), which is consistent with the present-day situation (de Vos et al., 2014). The link between the winter monsoon intensity and surface water productivity in the study area is confirmed by the difference between the $\delta^{13} \mathrm{C}$ values of the epipelagic $G$. ruber and the epibenthic C. mabahethi (Fig. 9). Low $\Delta \delta^{13} \mathrm{C}_{\mathrm{Gr}-\mathrm{Cm}}$ values indicate enhanced vertical mixing of the water column, which is associated with an increased supply of nutrients from subsurface waters into the photic zone based on enhanced surface water productivity.

\subsection{Sea-level changes, sedimentation processes and benthic ecosystem dynamics}

The close association of changes in sediment composition (i.e. bulk grain size, carbonate content) at site SO236-052 with the LR04 stable benthic isotope stack (Lisiecki and Raymo, 2005) suggests a dominant influence of sea-level changes on the depositional environments of the Maldives Inner Sea. This is also corroborated by the $\mathrm{Sr} / \mathrm{Ca}$ variations in the core. In periplatform ooze, i.e. areas around shallowwater carbonate banks and higher $\mathrm{Sr}$ contents are a consequence of a higher input of shallow-water aragonite (Dunbar and Dickens, 2003), which is produced in the neritic parts of the platforms and exported to the areas around the platform by currents. 
As shown by previous studies, variations in the total organic carbon content in the Inner Sea sediments are considerably triggered by sea-level and ocean current changes (Betzler et al., 2016). Thus, the observed changes in bottom currents likely influenced the lateral transport of suspended organic particles, as is suggested by variations in the relative abundance of suspension feeders in the different benthic foraminiferal assemblages (Figs. 7, 8, Table 2). The dominance of $D$. araucana during MIS 5 and $C$. mabahethi during MIS 6 and MIS 1 indicates phases of enhanced lateral food supply, which for the interglacial periods (MIS 5, MIS 1) correlate with reconstructed higher current velocities and sealevel highstands (Fig. 6). This is shown by the higher sortable silt data at site SO236-052, implying higher bottom current velocities, which is also supported by the higher amplitude of change and the sortable silt values of the drift deposits recovered by core M74/4-1143. The different sortable silt amplitudes of both settings in the Maldives are due to the restriction of the central part of the Inner Sea (core SO236-0524 ), whereas in comparison the deposition area in the Kardiva Channel (core M74/4-1143) is known to be exposed by much stronger current regimes since the Late Pleistocene (Betzler et al., 2013b; Reolid et al., 2017).

The interglacial intervals (mainly MIS 5 and MIS 7; Fig. 6) contain high abundances of meroplanktonic benthic foraminifera (Cymbaloporetta, Tretomphaloides), which build floating chambers for dispersal (Banner et al., 1985; Alve, 1999). These taxa are commonly found in shelf environments (Milker and Schmiedl, 2012). Their acme during the last interglacial maximum at upper bathyal depth in the Maldives Inner Sea coincides with an almost absence of other displaced species from reef and lagoon environments, such as Elphidium, Amphistegina and Operculina (Parker and Gischler, 2011). This implies a repeated colonization of upper bathyal environments with meroplanktonic taxa from submerged neritic environments during sea-level highstands and conditions of strengthened bottom water velocity.

\subsection{Changes in intermediate water circulation and oxygenation}

The epibenthic stable carbon isotope record of core SO236052-4 lacks a coherent glacial-interglacial pattern but reveals an overall $\delta^{13} \mathrm{C}_{\mathrm{Cm}}$ increase of $\sim 0.5 \%$ over the past $200 \mathrm{kyr}$ (Fig. 10). Long-term trends of similar magnitude have been recorded from sites in the south-western Pacific Ocean, which were particularly bathed by the welloxygenated Antarctic Intermediate Water mass (AAIW) during warm intervals (Thiede et al., 1999; Pahnke and Zahn, 2005; Elmore et al., 2015; Ronge et al., 2015; Fig. 10). The general resemblance of relative changes in epibenthic $\delta^{13} \mathrm{C}$ records from different regions suggests a significant and super-regional role of the AAIW in ventilation of the upper bathyal environments in the Maldives Inner Sea, which is consistent with the modern oceanographic situation (You, 1998).

Following the approach of Hoogakker et al. (2015) we estimated the changes in the oxygen content of the intermediate water mass of the Maldives Inner Sea based on the $\Delta \delta^{13} \mathrm{C}_{C m-G a}$ signal, i.e. the difference between the $\delta^{13} \mathrm{C}$ values of the epifaunal $C$. mabahethi and the deep infaunal $G$. affinis s.l. The resulting $\left[\mathrm{O}_{2}\right]$ concentrations display significant power in the precession band ( $23 \mathrm{kyr}$ period), with oxic and low oxic conditions related to Northern Hemisphere insolation maxima and minima, but they never dropped substantially below $45 \mu \mathrm{mol} \mathrm{kg}^{-1}\left(\approx 1 \mathrm{~mL} \mathrm{~L}^{-1}\right.$; Fig. 9). Moreover, the oxic to low oxic conditions did not seem to pose stress to the benthic foraminiferal fauna. Instead, the proportion of the deep infauna increases exponentially under dysoxic conditions, i.e. at $\left[\mathrm{O}_{2}\right]$ values significantly below $1 \mathrm{~mL} \mathrm{~L}^{-1}$ (Jorissen et al., 2007). The lack of dysoxic conditions at site SO236-052 at any time in the past $200 \mathrm{kyr}$ is corroborated by the persistently high diversity across glacial and interglacial periods and the low abundance of deep infaunal taxa. However, the reconstructed $\left[\mathrm{O}_{2}\right]$ changes in intermediate waters at site $\mathrm{SO} 236-052$ resemble those from the deep OMZ of the western Arabian Sea, which is influenced by the advection of oxygen-rich North Atlantic Deep Water (NADW; Schmiedl and Mackensen, 2006). The dependence of oxygen changes in Indian Ocean water masses on the inflow of Atlantic and Antarctic water masses is corroborated by a number of recent observations from the northwestern and south-eastern Arabian Sea (Pattan and Pearce, 2009; Das et al., 2017; Naik et al., 2017). We therefore assume that the OMZ variability in the Maldives Inner Sea is influenced by the overall strength and lateral southward expansion of the Arabian Sea OMZ and by local monsoonrelated organic matter fluxes and oxygen consumption, but it is additionally controlled by the ventilation of southernderived oxygen-rich intermediate water (AAIW). The oceanwide linkage of intermediate water ventilation can be assumed due to the general resemblance of our epibenthic stable carbon isotope record to comparable records from other areas. On the other hand, the significant variability of our new oxygen reconstruction from the Maldives Inner Sea in the precession band and its resemblance to the reconstruction from the Arabian Sea suggests an additional influence of monsoon-driven biogeochemical processes. The resulting changes in the biogeochemical processes at site SO236-052 are illustrated by the establishment and long-term persistence of the benthic foraminiferal assemblage 3 underlining the positive response of $N$. proboscidea and associated species such as $H$. elegans and $D$. bertheloti to moderately reduced oxygen and increased food levels.

The long period of lowered $\left[\mathrm{O}_{2}\right]$ values below $60 \mu \mathrm{mol} \mathrm{kg}{ }^{-1}$ centred at MIS 4-3 coincides with a marked monsoon and upwelling maximum in the Arabian Sea (Hermelin and Shimmield, 1995; Clemens and Prell, 2003; Leuschner and Sirocko, 2003; Caley et al., 2011a, b), which 


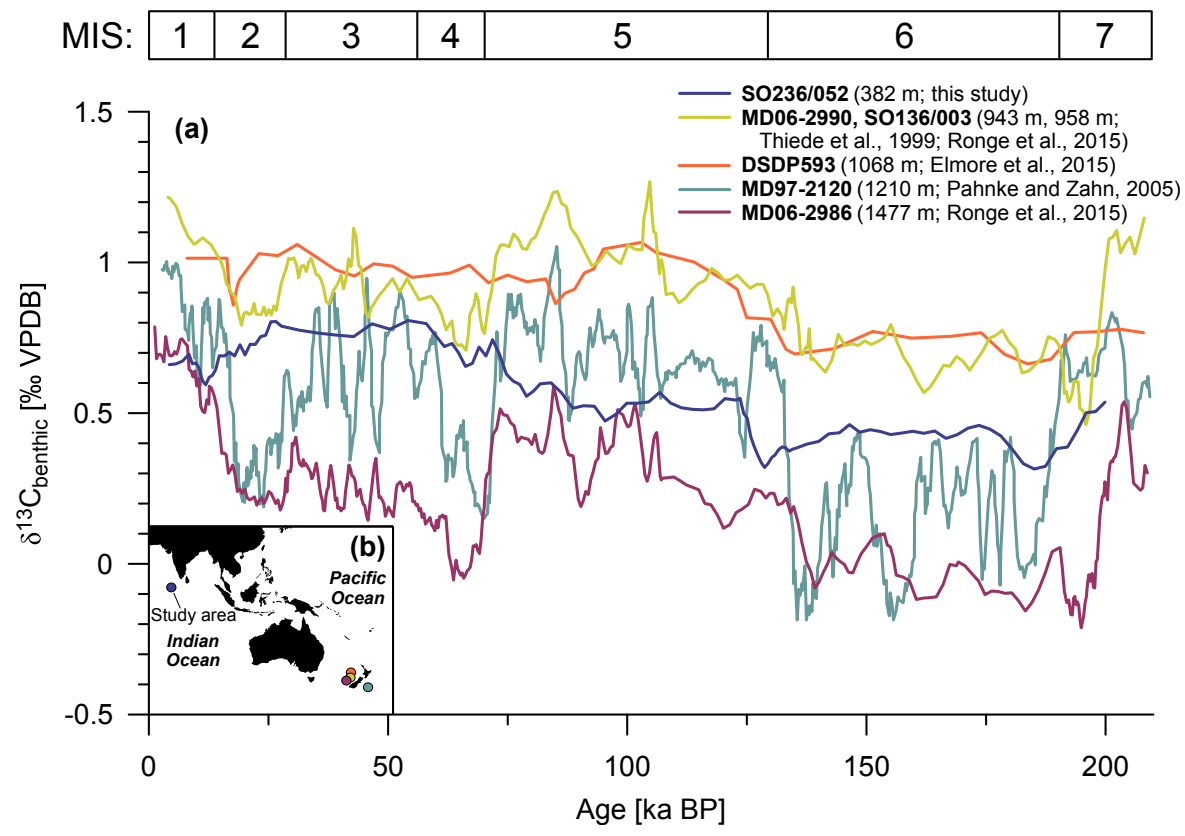

Figure 10. Comparison of epibenthic $\delta^{13} \mathrm{C}$ records from intermediate water depth in the equatorial Indian and temperate south-western Pacific oceans; (a) $\delta^{13} \mathrm{C}$ record of $C$. mabahethi (blue) from the Maldives Inner Sea (SO236-052) in comparison to $\delta^{13} \mathrm{C}$ records from the south-western Pacific Ocean, which were mainly generated from Cibicidoides wuellerstorfi, C. cicatricosa and C. kullenbergi and represent different water depths (Thiede et al., 1999; Pahnke and Zahn, 2005; Elmore et al., 2015; Ronge et al., 2015). Data of MD97-2120 were traced after Pahnke and Zahn (2005). All lines represent 5-point running averages. (b) Simplified map of the Indian Ocean and the south-western Pacific Ocean with the location of the study sites.

caused a strengthening and deepening of the OMZ (AlmogiLabin et al., 2000; Den Dulk et al., 2000; Schmiedl and Leuschner, 2005). The expansion of the Arabian Sea OMZ southward into the equatorial region likely preconditioned the oxygen levels of intermediate waters in the Maldives Inner Sea. There, oxygen minima were further lowered by the reduced glacial advection of the oxygen-rich AAIW and enhanced regional microbial oxygen consumption, reflecting a superposition of high- and low-latitude climate signals. Additionally, an abrupt $\left[\mathrm{O}_{2}\right]$ drop occurred at the end of the last glaciation, suggesting a short phase of reduced AAIW advection or increased surface water productivity and related oxygen consumption at depth (Fig. 9).

The present OMZ in the north-western Indian Ocean extends from the northern Arabian Sea into the tropical Indian Ocean (Reid, 2003), reflecting the reduced ventilation of intermediate water masses (due to its remote position) and the biogeochemical processes related to monsoon-induced organic matter fluxes and microbial oxygen consumption. Indeed, the oxygen concentrations in the Indian Ocean display a gradient with very low values in the northern Arabian Sea and increasing values to the south. This gradient illustrates a clear relation to the monsoon-related biogeochemical processes in the Arabian Sea, but it is also a reflection of the remote position of the Arabian Sea in terms of intermediate water ventilation. Nevertheless, a monsoon-induced strengthen- ing of the OMZ in the Arabian Sea (as during MIS 3) will result in an increase in the north-south oxygen gradient in the entire north-western Indian Ocean, which should then also be detected in the Maldives Inner Sea at a lower amplitude.

Evaluations of calcareous nanoplankton records, which are used as indicators for surface productivity, from sediment cores of the equatorial Indian and Pacific Ocean reveal significant variability in the precession band and are coherent and in phase with February equatorial insolation (Beaufort et al., 1997, 2001). This orbital pattern suggested a close link of equatorial Indian Ocean productivity to the strength of the Indian Ocean Equatorial Westerlies (IEW) and an ENSOlike forcing of equatorial surface ocean productivity during the Late Quaternary (Beaufort et al., 2001). Accordingly, regional productivity and organic matter fluxes in the wider Maldives area may have also been influenced by changes in the strength of the IEW. However, a strong IEW influence in the Maldives Inner Sea is questioned by the low precessional variability observed in our productivity proxies and the close association of modern phytoplankton blooms in this region with the NE monsoon (Sasamal, 2007; de Vos et al., 2014). To summarize, our new results imply that on orbital timescales changes in the winter monsoon and AAIW advection seem to exert the dominant influence on upper bathyal environments in the Maldives Inner Sea. 


\section{Conclusions}

The integrated evaluation of sedimentological, geochemical and micropaleontological proxy records from the Maldives Inner Sea (tropical Indian Ocean) furthers our understanding of links between equatorial climate variability, sea-level changes, changes in intermediate water ventilation and benthic ecosystem dynamics on orbital timescales during the past $200 \mathrm{kyr}$. The main conclusions are the following.

1. Aeolian dust fluxes were considerably enhanced during glacial intervals (MIS 6 and MIS 4-2) as indicated by increased $\mathrm{Fe} / \mathrm{Al}, \mathrm{Ti} / \mathrm{Al}$ and $\mathrm{Si} / \mathrm{Ca}$ ratios, general coarsening of the bulk sediment and increased abundance of agglutinated benthic foraminiferal taxa, which use the siliciclastic grains for test formation. The enhanced dust input was linked to phases of generally increased atmospheric dust loads and NE winds, suggesting a close linkage of Maldives marine environments to the aridity of the central Asian loess areas and the strength of the Indian winter monsoon.

2. Increased vertical mixing during glacial phases of intensified winter monsoon resulted in enhanced surface water productivity and associated organic carbon fluxes to the sea floor as indicated by TOC values and the composition of the benthic foraminiferal fauna. The Cibicidoides mabahethi (assemblage 2) and Neouvigerina proboscidea (assemblage 3) faunas dominate during MIS 6 and MIS 4-2, respectively, suggesting differences in the amount and quality of food delivery for the two glacial intervals. The Br XRF counts and the TOC record reveal additional variability in the precessional band (as shown with the Blackman-Tukey spectral analysis; Fig. 4), which is inversely correlated with Northern Hemisphere summer insolation underlining a close link of the regional vertical mixing of the water column and marine productivity to the Indian winter monsoon.

3. Glacial-interglacial changes in sea level controlled the downslope transport of sediment from the Maldives archipelago to the deep-sea environments and influenced the current strength at the benthic boundary layer of the Inner Sea, resulting in different grain sizes and substrates. The drift deposits recovered by core M74/41143 have shown that the highest current intensities occurred during and after the glacial terminations (Fig. 6). Bottom currents in general were stronger during interglacials than during glacials, although core $\mathrm{SO} 236-052-$ 4 shows lower current velocities and a lower amplitude of change. Stronger current intensities at the sea floor likely favoured the distribution of certain suspensionfeeding benthic foraminiferal taxa, such as D. araucana .

4. The long-term trend in the benthic $\delta^{13} \mathrm{C}$ record mirrors the basin-wide change in the composition of intermedi- ate waters, implying a close linkage to the main formation sites of the AAIW in the Southern Ocean. The precessional changes in the estimated oxygen concentrations of intermediate waters are coherent with changes in the deep Arabian Sea. This suggests an influence of the lateral expansion of oxygen minimum waters from the Arabian Sea into the equatorial intermediate Indian Ocean and modulation by inflowing AAIW from the south. The predominance of $N$. proboscidea during a long phase of reduced oxygen concentrations (with average oxygen concentrations around $50 \mu \mathrm{mol} \mathrm{kg}^{-1}$ ) during late MIS 5 to late MIS 3 suggests an adaption of this species to the particular biogeochemical conditions and food quality associated with low oxic conditions.

Data availability. All data records of core SO236-052-4 used and discussed in this paper are accessible at https://doi.pangaea.de/10. 1594/PANGAEA.882514 (Bunzel et al., 2017).

Competing interests. The authors declare that they have no conflict of interest.

Acknowledgements. We thank the masters, crews and the shipboard scientific parties of the R/V SONNE SO236 and $\mathrm{R} / \mathrm{V}$ METEOR M74/4 cruises for their excellent collaboration. Jutta Richarz is thanked for her support during grain size analyses, and Lisa Schönborn and Günther Meyer are thanked for technical support during stable isotope measurements. Aurora Elmore and Thomas Ronge are thanked for providing the stable carbon isotope records of the south-western Pacific Ocean (cores DSDP593, MD06-2986, MD06-2990/SO136/003), and we thank Yvonne Milker for the many helpful discussions. We acknowledge the two anonymous reviewers who helped to considerably improve this paper with detailed comments and suggestions. This research used data acquired at the XRF Core Scanner Lab at the MARUM Center for Marine Environmental Sciences, University of Bremen, Germany. This study was supported by grant 03G0236A from the Federal Ministry of Education and Research. The Ministry of Fisheries and Agriculture of the Maldives is thanked for granting the research permit for Maldivian waters.

Edited by: Luc Beaufort

Reviewed by: two anonymous referees

\section{References}

Allen, K., Roberts, S., and Murray, J. W.: Marginal marine agglutinated foraminifera: affinities for mineral phases, J. Micropaleontol., 35, 183-191, https://doi.org/10.1144/jm.18.2.183, 1999.

Almogi-Labin, A., Schmiedl, G., Hemleben, C., Siman-Tov, R., Segl, M., and Meischner, D.: The influence of the NE winter monsoon on productivity changes in the Gulf of Aden, NW Arabian Sea, during the last $530 \mathrm{ka}$ as recorded by foraminifera, Mar. 
Micropaleontol., 40, 295-319, https://doi.org/10.1016/S03778398(00)00043-8, 2000.

Altabet, M. A., Higginson, M. J., and Murray, D. W.: The effect of millennial-scale changes in Arabian Sea denitrification on atmospheric $\mathrm{CO}_{2}$, Nature, 415, 159-162, https://doi.org/10.1038/415159a, 2002.

Alve, E.: Colonization of new habitats by benthic foraminifera: a review, Earth-Sci. Rev., 46, 167-185, https://doi.org/10.1016/S0012-8252(99)00016-1, 1999.

Anderson, R. F., Barker, S., Fleisher, M., Gersonde, R., Goldstein, S. L., Kuhn, G., Mortyn, P. G., Pahnke, K., and Sachs, J. P.: Biological response to millennial variability of dust and nutrient supply in the Subantarctic South Atlantic Ocean, Philos. T. R. Soc. A, 372, 1-17, https://doi.org/10.1098/rsta.2013.0054, 2014.

Armynot du Châtelet, E., Bout-Roumazeilles, V., Coccioni, R., Frontalini, F., Guillot, F., Kaminski, M. A., Recourt, P., Riboulleau, A., Trentesaux, A., Tribovillard, N., and Ventalon, S.: Environmental control on shell structure and composition of agglutinated foraminifera along a proximal-distal transect in the Marmara Sea, Mar. Geol., 335, 114-128, https://doi.org/10.1016/j.margeo.2012.10.013, 2013.

Aston, S. R., Chester, R., Johnson, L. R., and Padgham, R. C.: Eolian dust from the lower atmosphere of the eastern Atlantic and Indian Oceans, China Sea and Sea of Japan, Mar. Geol., 14, 1528, https://doi.org/10.1016/0025-3227(73)90040-6, 1973.

Backhaus, K., Erichson, B., Plinke, W., and Weiber, R.: Multivariate Analysemethoden, Springer, Berlin, Heidelberg, New York, 1575, 2008.

Badawi, A., Schmiedl, G., and Hemleben, C.: Impact of late Quaternary environmental changes on deep-sea benthic foraminiferal faunas of the Red Sea, Mar. Micropaleontol., 58, 13-30, https://doi.org/10.1016/j.marmicro.2005.08.002, 2005.

Banner, F. T., Pereira, C. P. G., and Desai, D.: "Tretomphaloid" float chambers in the Discorbidae and Cymbaloporidae, J. Foramin. Res., 15, 159-174, https://doi.org/10.2113/gsjfr.15.3.159, 1985.

Beaufort, L., Lancelot, Y., Camberlin, P., Cayre, O., Vincent, E., Bassinot, F., and Labeyrie, L.: Insolation cycles as a major control of equatorial Indian Ocean Primary Production, Science, 278, 1451-1454, https://doi.org/10.1126/science.278.5342.1451, 1997.

Beaufort, L., de Garidel-Thoron, T., Mix, A. C., and Pisias, N. G.: ENSO-like forcing on oceanic primary production during the Late Pleistocene, Science, 293, 2440-2444, https://doi.org/10.1126/science.293.5539.2440, 2001.

Betzler, C., Hübscher, C., Lindhorst, S., Reijmer, J. J. G., Römer, M., Droxler, A. W., Fürstenau, J., and Lüdmann, T.: Monsoonal-induced partial carbonate platform drowning (Maldives, Indian Ocean), Geology, 37, 867-870, https://doi.org/10.1130/G25702A.1, 2009.

Betzler, C., Fürstenau, J., Lüdmann, T., Hübscher, C., Lindhorst, S., Paul, A., Reijmer, J. J. G., and Droxler, A. W.: Sea-level and ocean-current control on carbonate-platform growth, Maldives, Indian Ocean, Basin Res., 25, 172-196, https://doi.org/10.1111/j.1365-2117.2012.00554.x, 2013a.

Betzler, C., Lüdmann, T., Hübscher, C., and Fürstenau, J.: Current and sea-level signals in periplatform ooze (Neogene, Maldives, Indian Ocean), Sediment. Geol., 290, 126-137, https://doi.org/10.1016/j.sedgeo.2013.03.011, 2013b.
Betzler, C., Eberli, G. P., Kroon, D., Wright, J. D., Swart, P. K., Nath, B. N., Alvarez-Zarikian, C. A., Alonso-García, M., Bialik, O. M., Blättler, C. L., Guo, J. A., Haffen, S., Horozal, S., Inoue, M., Jovane, L., Lanci, L. Laya, J. C., Mee, A. L. H., Lüdmann, T., Nakakuni, M., Niino, K., Petruny, L. M., Pratiwi, S. D., Reijmer, J. J. G., Reolid, J., Slagle, A. L., Sloss, C. R., Su, X., Yao, Z., and Young, J. R.: The abrupt onset of the modern South Asian Monsoon winds, Sci. Rep., 6, 29838, https://doi.org/10.1038/srep29838, 2016.

Bianchi, G. G., Hall, I. R., McCave I. N., and Joseph, L.: Measurement of the sortable silt current speed proxy using the Sedigraph 5100 and Coulter Multisizer IIe: Precision and accuracy, Sedimentology, 46, 1001-1014, https://doi.org/10.1046/j.13653091.1999.00256.x, 1999.

Blott, S. J. and Pye, K.: GRADISTAT: a grain size distribution and statistics package for the analysis of unconsolidated sediments, Earth Surf. Proc. Land., 26, 1237-1248, https://doi.org/10.1002/esp.261, 2001.

Böning, P. and Bard, E.: Millennial/centennial-scale thermocline ventilation changes in the Indian Ocean as reflected by aragonite preservation and geochemical variations in Arabian Sea sediments, Geochim. Cosmochim. Ac., 73, 6771-6788, https://doi.org/10.1016/j.gca.2009.08.028, 2009.

Boyd, P. W., Watson, A. J., Law, C. S., Abraham, E. R., Trull, T., Murdoch, R., Bakker, D. C. E., Bowie, A. R., Buesseler, K. O., Chang, H., Charette, M., Croot, P., Downing, K., Frew, R., Gall, M., Hadfield, M., Hall., J., Harvey, M., Jameson, G., LaRoche, J., Liddicoat, M., Ling, R., Maldonado, M. T., McKay, R. M., Nodder, S., Pickmere, S., Pridmore, R., Rintoul, S., Safi, K., Sutton, P., Strzepek, R., Tanneberger, K., Turner, S., Waite, A., and Zeldis, J.: A mesoscale phytoplankton bloom in the polar Southern Ocean simulated by iron fertilization, Nature, 407, 695-702, https://doi.org/10.1038/35037500, 2000.

Bunzel, D., Schmiedl, G., Lindhorst, S., Mackensen, A., Reolid, J., Romahn, S., and Betzler, C.: Benthic foraminifera census counts and compilation of the isotope, grain size, TOC, $\mathrm{CaCO}_{3}$ and XRF data records of sediment core SO236_052-4, PANGAEA, https://doi.org/10.1594/PANGAEA.882514, 2017.

Caley, T., Malaizé, B., Zaragosi, S., Rossignol, L., Bourget, J., Eynaud, F., Martinez, P., Giraudeau, J., Charlier, K., and EllouzZimmermann, N.: New Arabian Sea records help decipher orbital timing of Indo-Asian monsoon, Earth Planet. Sc. Lett., 308, 433-444, https://doi.org/10.1016/j.eps1.2011.06.019, 2011a.

Caley, T., Malaizé, B., Revel, M., Ducassou, E., Wainer, K., Ibrahim, M., Shoeaib, D., Migeon, S., and Marieu, V.: Orbital timing of the Indian, East Asian and African boreal monsoons and the concept of a "global monsoon", Quaternary Sci. Rev., 30, 3705-3715, https://doi.org/10.1016/j.quascirev.2011.09.015, 2011b.

Caley, T., Zaragosi, S., Bourget, J., Martinez, P., Malaizé, B., Eynaud, F., Rossignol, L., Garlan, T., and Ellouz-Zimmermann, N.: Southern Hemisphere imprint for Indo-Asian summer monsoons during the last glacial period as revealed by Arabian Sea productivity records, Biogeosciences, 10, 7347-7359, https://doi.org/10.5194/bg-10-7347-2013, 2013.

Chauhan, O. S. and Shukla, A. S.: Evaluation of the influence of monsoon climatology on dispersal and sequestration of continental flux over the southeastern Arabian Sea, Mar. Geol., 371, 44-56, https://doi.org/10.1016/j.margeo.2015.10.018, 2016. 
Clemens, S. C. and Prell, W. L.: Late Pleistocene variability of Arabian Sea summer monsoon winds and continental aridity: Eolian records from the lithogenic component of deep-sea sediments, Paleoceanography, 5, 109-145, https://doi.org/10.1029/PA005i002p00109, 1990.

Clemens, S. C. and Prell, W. L.: A 350000 year summer-monsoon multi-proxy stack from the Owen Ridge, Northern Arabian Sea, Mar. Geol., 201, 35-51, https://doi.org/10.1016/S00253227(03)00207-X, 2003.

Clemens, S. C., Prell, W. L., Murray, D. W., Shimmield, G., and Weedon, G.: Forcing mechanisms of the Indian Ocean monsoon, Nature, 353, 720-725, 1991.

Clemens, S. C., Murray, D. W., and Prell, W. L.: Nonstationary Phase of the Plio-Pleistocene Asian Monsoon, Science, 274, 943-948, 1996.

Corliss, B. H.: Microhabitats of benthic foraminifera within deep-sea sediments, Nature, 314, 435-438, https://doi.org/10.1038/314435a0, 1985.

Corliss, B. H. and Chen, C.: Morphotype patterns of Norwegian Sea deep-sea benthic foraminifera and ecological implications, Geology, 16, 716-719, https://doi.org/10.1130/00917613(1988)016<0716:MPONSD>2.3.CO;2, 1988.

Costa, K. M., McManus, J. F., Anderson, R. F., Ren, H., Sigman, D. M., Winckler, G., Fleisher, M. Q., Marcantonio, F., and Ravelo, A. C.: No iron fertilization in the equatorial Pacific Ocean during the last ice age, Nature, 529, 519-522, https://doi.org/10.1038/nature16453, 2016.

Croudace, I. W. and Rothwell, R. G.: Micro-XRF Studies of Sediment Cores: Applications of a non-destructive tool for the environmental sciences, Developments in Paleoenvironmental Research 17, Springer, Dordrecht, Heidelberg, New York, London, 1-656, 2015.

Dansgaard, W., Johnsen, S. J., Clausen, H. B., Dahl-Jensen, D., Gundestrup, N. S., Hammer, C. U., Hvidberg, C. S., Steffensen, J. P., Sveinbjörnsdottir, A. E., Jouzel, J., and Bond, G.: Evidence for general instability of past climate from a $250-\mathrm{kyr}$ ice-core record, Nature, 364, 218-220, https://doi.org/10.1038/364218a0, 1993.

Das, M., Singh, R. K., Gupta, A. K., and Bhaumik, A. K.: Holocene strengthening of the oxygen minimum zone in the northwestern Arabian Sea linked to changes in intermediate water circulation or Indian monsoon intensity?, Palaeogeogr. Palaeocl., 483, 125135, https://doi.org/10.1016/j.palaeo.2016.10.035, 2017.

De, S. and Gupta, A. K.: Deep-sea faunal provinces and their inferred environments in the Indian Ocean based on distribution of Recent benthic foraminifera, Palaeogeogr. Palaeocl., 291, 429442, https://doi.org/10.1016/j.palaeo.2010.03.012, 2010.

Debenay, J.-P.: A Guide to 1000 Foraminifera from Southwestern Pacific, New Caledonia, IRD Éditions, Publications Scientifiques du Muséum, Paris, France, CP41, 1-384, 2012.

deMenocal, P. B., Bloemendal, J., and King, J.: A rock-magnetic record of monsoonal dust deposition to the Arabian Sea: Evidence for a shift in the mode of deposition at 2.4 Ma, Proceedings of the Ocean Drilling Program, Scientific Results, 117, 389-407, 1991.

Den Dulk, M., Reichart, G. J., van Heyst, S., Zachariasse, W. J., and Van der Zwaan, G. J.: Benthic foraminifera as proxies of organic matter flux and bottom water oxygenation? A case history from the northern Arabian Sea, Palaeogeogr. Palaeocl., 161, 337-359, https://doi.org/10.1016/S0031-0182(00)00074-2, 2000.

Deplazes, G., Lückge, A., Peterson, L. C., Timmermann, A., Hamann, Y., Hughen, K. A., Röhl, U., Laj, C., Cane, M. A., Sigman, D. M., and Haug, G. H.: Links between tropical rainfall, and North Atlantic climate during the last glacial period, Nat. Geosci., 6, 213-217, https://doi.org/10.1038/NGEO1712, 2013.

de Vos, A., Pattiaratchi, C. B., and Wijeratne, E. M. S.: Surface circulation and upwelling patterns around Sri Lanka, Biogeosciences, 11, 5909-5930, https://doi.org/10.5194/bg-11-59092014, 2014.

Ding, Z., Liu, T., Rutter, N. W., Yu, Z., Guo, Z., and Zhu, R.: Ice-Volume Forcing of East Asian Winter Monsoon Variations in the Past 800000 Years, Quaternary Res., 44, 149-159, https://doi.org/10.1006/qres.1995.1059, 1995.

di Primio, R. and Leythaeuser, D.: Quantification of the effect of carbonate redistribution by pressure solution in organic-rich carbonates, Mar. Petrol. Geol., 12, 735-739, https://doi.org/10.1016/0264-8172(95)93598-X, 1995.

Duce, R. A. and Tindale, N. W.: Atmospheric transport of iron and its deposition in the ocean, Limnol. Oceanogr., 36, 1715-1726, https://doi.org/10.4319/lo.1991.36.8.1715, 1991.

Duleba, W., Debenay, J.-P., Eichler, B. B., and de Mahiques, M. M.: Holocene Environmental and Water Circulation Changes: Foraminifer Morphogroups Evidence in Flamengo Bay (SP, Brazil), J. Coastal Res., 15, 554-571, 1999.

Dunbar, G. B. and Dickens, G. R.: Late Quaternary shedding of shallow-water marine carbonate along a tropical mixed siliciclastic-carbonate shelf: Great Barrier Reef, Australia, Sedimentology, 50, 1061-1077, https://doi.org/10.1046/j.13653091.2003.00593.x, 2003.

Dutta, K., Bhushan, R., and Somayajulu, B. L. K.: $\Delta$ R Correction Values for the Northern Indian Ocean, Radiocarbon, 43, 483488, https://doi.org/10.1017/S0033822200038376, 2001.

Edelmann-Furstenberg, Y., Scherbacher, M., Hemleben, C., and Almogi-Labin, A.: Deep-sea benthic foraminifera from the central Red Sea, J. Foramin. Res., 31, 48-59, 2001.

Elmore, A. C., McClymont, E. L., Elderfield, H., Kender, S., Cook, M. R., Leng, M. J., Greaves, M., and Misra, S.: Antarctic Intermediate Water properties since $400 \mathrm{ka}$ recorded in infaunal (Uvigerina peregrina) and epifaunal (Planulina wuellerstorfi) benthic foraminifera, Earth Planet. Sc. Lett., 428, 193203, https://doi.org/10.1016/j.eps1.2015.07.013, 2015.

Folk, R. L. and Ward, W. C.: Brazos River Bar: A Study in the Significance of Grain Size Parameters, J. Sediment. Petrol., 27, 3-26, 1957.

Fontanier, C., Jorissen, F. J., Licari, L., Alexandre, A., Anschutz, P., and Carbonel, P.: Live benthic foraminiferal faunas from the Bay of Biscay: faunal density, composition, and microhabitats, Deep-Sea Res. Pt. I, 49, 751-785, https://doi.org/10.1016/S09670637(01)00078-4, 2002.

Gao, Y., Kaufman, Y. J., Tanré, D., Kolber, D., and Falkowski, P. G.: Seasonal Distribution of Aeolian Iron Fluxes to the Global Ocean, Geophys. Res. Lett., 28, 29-32, 2001.

Grand, M. M., Measures, C. I., Hatta, M., Hiscock, W. T., Buck, C. S., and Landing, W. M.: Dust deposition in the eastern Indian Ocean: The ocean perspective from Antarctica to the Bay of Bengal, Global Biogeochem. Cy., 29, 357-374, https://doi.org/10.1002/2014GB004898, 2015. 
Guo, Z. T., Ruddiman, W. F., Hao, Q. Z., Wu, H. B., Qiao, Y. S., Zhu, R. X., Peng, S. Z., Wei, J. J., Yuan, B. Y., and Liu, T. S.: Onset of Asian desertification by $22 \mathrm{Myr}$ ago inferred from loess deposits in China, Nature, 416, 159-163, https://doi.org/10.1038/416159a, 2002.

Gupta, A. K. and Srinivasan, M. S.: Uvigerina proboscidea abundances and paleoceanography of the northern Indian Ocean DSDP Site 214 during the Late Neogene, Mar. Micropaleontol., 19, 355-367, https://doi.org/10.1016/0377-8398(92)90038L, 1992.

Gupta, A. K. and Thomas, E.: Initiation of Northern Hemisphere glaciation and strengthening of the northeast Indian monsoon: Ocean Drilling Program Site 758, eastern equatorial Indian Ocean, Geology, 31, 47-50, https://doi.org/10.1130/00917613(2003)031<0047:IONHGA>2.0.CO;2, 2003.

Gupta, A. K., Anderson, D. M., and Overpeck, J. T.: Abrupt changes in the Asian southwest monsoon during the Holocene and their links to the North Atlantic Ocean, Nature, 421, 354357, https://doi.org/10.1038/nature01340, 2003.

Hall, I. R., McCave, I. N., Chapman, M. R., and Shackleton, N. J.: Coherent deep flow variation in the Iceland and American basins during the last interglacial, Earth Planet. Sc. Lett., 164, 15-21, https://doi.org/10.1016/S0012-821X(98)00209-X, 1998.

Hao, Q., Wang, L., Oldfield, F., Peng, S., Qin, L., Song, Y., Xu, B., Qiao, Y., Bloemendal, J., and Guo, Z.: Delayed build-up of Arctic ice sheets during 400000 -year minima in insolation variability, Nature, 490, 393-396, https://doi.org/10.1038/nature11493, 2012.

Harrison, T. M., Copeland, P., Kidd, W. S. F., and Yin, A.: Raising Tibet, Science, 255, 1663-1670, 1992.

Hastenrath, S., Nicklis, A., and Greischar, L.: Atmospherichydrospheric mechanisms of climate anomalies in the western equatorial Indian Ocean, J. Geophys. Res., 98, 20219-20235, https://doi.org/10.1029/93JC02330, 1993.

Hermelin, J. O. R. and Shimmield, G. B.: Impact of productivity events on the benthic foraminiferal fauna in the Arabian Sea over the last 150000 years, Paleoceanography, 10, 85-116, https://doi.org/10.1029/94PA02514, 1995.

Holbourn, A., Henderson, A. S., and MacLeod, N.: Atlas of Benthic Foraminifera, Wiley-Blackwell, John Wiley \& Sons Ltd. Publication, Natural History Museum, 1-642, https://doi.org/10.1002/9781118452493, 2013.

Hoogakker, B. A. A., Elderfield, H., Schmiedl, G., McCave, I. N., and Rickaby, R. E. M.: Glacial-interglacial changes in bottomwater oxygen content on the Portuguese margin, Nat. Geosci., 8, 40-43, https://doi.org/10.1038/ngeo2317, 2015.

Hottinger, L., Halicz, E., and Reiss, Z.: Recent Foraminiferida from the Gulf of Aqaba, Red Sea, Ljubljana, Slovenska Akademija Znanosti in Umetnosti, Razred za naravoslovne vede, Classis IV: Historia naturalis, 33, 1-179, 1993.

Itambi, A. C., von Dobeneck, T., Mulitza, S., Bickert, T., and Heslop, D.: Millennial-scale northwest African droughts related to Heinrich events and Dansgaard-Oeschger cycles: Evidence in marine sediments from offshore Senegal, Paleoceanography, 24, PA1205, https://doi.org/10.1029/2007PA001570, 2009.

Ivanova, E., Schiebel, R., Singh, A. D., Schmiedl, G., Niebler, H.S., and Hemleben, C.: Primary production in the Arabian Sea during the last 135000 years, Palaeogeogr. Palaeocl., 197, 6182, https://doi.org/10.1016/S0031-0182(03)00386-9, 2003.
Jickells, T. D., An, Z. S., Andersen, K. K., Baker, A. R., Bergametti, G., Brooks, N., Cao, J. J., Boyd, P. W., Duce, R. A., Hunter, K. A., Kawahata, H., Kubilay, N., LaRoche, J., Liss, P. S., Mahowald, N., Prospero, J. M., Ridgwell, A. J., Tegen, I., and Torres, R.: Global Iron Connections Between Desert Dust, Ocean Biogeochemistry, and Climate, Science, 308, 6771, https://doi.org/10.1126/science.1105959, 2005.

Jones, R. W.: The Challenger Foraminifera, The Natural History Museum, London, Oxford University Press Inc., New York, USA, 1-290, 1994.

Jorissen, F. J. and Wittling, I.: Ecological evidence from livedead comparisons of benthic foraminiferal faunas off Cape Blanc (Northwest Africa), Palaeogeogr. Palaeocl., 149, 151-170, https://doi.org/10.1016/S0031-0182(98)00198-9, 1999.

Jorissen, F. J., de Stigter, H. C., and Widmark, J. G. V.: A conceptual model explaining benthic foraminiferal microhabitats, Mar. Micropaleontol., 26, 3-15, https://doi.org/10.1016/03778398(95)00047-X, 1995.

Jorissen, F. J., Fontanier, C., and Thomas, E.,: Paleoceanographical proxies based on deep-sea benthic foraminiferal assemblage characteristics, in: Proxies in Late Cenozoic paleoceanography, edited by: Hillaire-Marcel, C. and De Vernal, A., Developments in Mar. Geol., Elsevier, Amsterdam, the Netherlands, 277-328, 2007.

Jung, S. J. A., Ganssen, G. M., and Davies, G. R.: Multidecadal variations in the early Holocene outflow of Red Sea Water into the Arabian Sea, Paleoceanography, 16, 658-668, https://doi.org/10.1029/2000PA000592, 2001.

Koho, K. A., García, R., de Stigter, H. C., Epping, E., Koning, E., Kouwenhoven, T. J., and Van der Zwaan, G. J.: Sedimentary labile organic carbon and pore water redox control on species distribution of benthic foraminifera: A case study from LisbonSetúbal Canyon (southern Portugal), Prog. Oceanogr., 79, 55-82, https://doi.org/10.1016/j.pocean.2008.07.004, 2008.

Laskar, J., Robutel, P., Joutel, F., Gastineau, M., Correia, A. C. M., and Levrard, B.: A long term numerical solution for the insolation quantities of the Earth, Astron. Astrophys., 428, 261-285, https://doi.org/10.1051/0004-6361:20041335, 2004.

Leuschner, D. C. and Sirocko, F.: Orbital insolation forcing of the Indian Monsoon - a motor for global climate changes?, Palaeogeogr. Palaeocl., 197, 83-95, https://doi.org/10.1016/S00310182(03)00387-0, 2003.

Licari, L. N., Schumacher, S., Wenzhöfer, F., Zabel, M., and Mackensen, A.: Communities and microhabitats of living benthic foraminifera from the tropical East Atlantic: Impact of different productivity regimes, J. Foramin. Res., 33, 10-31, https://doi.org/10.2113/0330010, 2003.

Linke, P. and Lutze, G. F.: Microhabitat preferences of benthic foraminifera-a static concept or a dynamic adaptation to optimize food acquisition?, Mar. Micropaleontol., 20, 215-234, https://doi.org/10.1016/0377-8398(93)90034-U, 1993.

Lisiecki, L. E. and Raymo, M. E.: A Pliocene-Pleistocene stack of 57 globally distributed benthic $\delta^{18} \mathrm{O}$ records, Paleoceanography, 20, PA1003, https://doi.org/10.1029/2004PA001071, 2005.

Liu, T., Ding, Z., and Rutter, N.: Comparison of Milankovitch periods between continental loess and deep sea records over the last 2.5 Ma, Quaternary Sci. Rev., 18, 1205-1212, https://doi.org/10.1016/S0277-3791(98)00110-3, 1999. 
Loeblich, A. R. and Tappan, H.: Foraminiferal Genera and their Classification, Van Nostrand Reinhold Company, New York, USA, 1-2115, 1988.

Lourens, L. J., Wehausen, R., and Brumsack, H.-J.: Geological constraints on tidal dissipation and dynamical ellipticity of the Earth over the past three million years, Nature, 409, 1029-1033, https://doi.org/10.1038/35059062, 2001.

Lüdmann, T., Kalvelage, C., Betzler, C., Fürstenau, J., and Hübscher, C.: The Maldives, a giant isolated carbonate platform dominated by bottom currents, Mar. Petrol. Geol., 43, 326-340, https://doi.org/10.1016/j.marpetgeo.2013.01.004, 2013.

Lutze, G. F. and Thiel, H.: Epibenthic foraminifera from elevated microhabitats: Cibicidoides wuellerstorfi and Planulina ariminensis, J. Foramin. Res., 19, 153-158, https://doi.org/10.2113/gsjfr.19.2.153, 1989.

Maher, B. A., Prospero, J. M., Mackie, D., Gaiero, D., Hesse, P. P., and Balkanski, Y.: Global connections between aeolian dust, climate and ocean biogeochemistry at the present day and at the last glacial maximum, Earth-Sci. Rev., 99, 61-97, https://doi.org/10.1016/j.earscirev.2009.12.001, 2010.

Manabe, S. and Broccoli, A. J.: Mountains and Arid Climates of Middle Latitudes, Science, 247, 192-195, 1990.

Manighetti, B. and McCave, I. N.: Late glacial and Holocene palaeocurrents through South Rockall Gap, NE Atlantic Ocean, Paleoceanography, 10, 611-626, 1995.

Martin, J. H., Gordon, R. M., and Fitzwater, S. E.: The case for iron, Limnol. Oceanogr., 36, 1793-1802, 1991.

Martínez-García, A. Sigman, D. M., Ren, H., Anderson, R. F., Straub, M., Hodell, D. A., Jaccard, S. L., Eglinton, T. I., and Haug, G. H.: Iron fertilization of the Subantarctic Ocean during the Last Ice Age, Science, 343, 1347-1350, https://doi.org/10.1126/science.1246848, 2014.

McCave, I. N. and Hall, I. R.: Size sorting in marine muds: Processes, pitfalls, and prospects for paleoflowspeed proxies, Geochem. Geophy. Geosy., 7, 1-37, https://doi.org/10.1029/2006GC001284, 2006.

McCave, I. N., Manighetti, B., and Beveridge, N. A. S.: Circulation in the glacial North Atlantic inferred from grain-size measurements, Nature, 374, 149-152, https://doi.org/10.1038/374149a0, 1995a.

McCave, I. N., Manighetti, B., and Robinson, S. G.: Sortable silt and fine sediment size/composition slicing: Parameters for palaeocurrent speed and palaeoceanography, Paleoceanography, 10, 593-610, https://doi.org/10.1029/94PA03039, 1995b.

Milker, Y. and Schmiedl, G.: A taxonomic guide to modern benthic shelf foraminifera of the western Mediterranean Sea, Palaeontol. Electron., 15, 1-134, 2012.

Möbius, J., Gaye, B., Lahajnar, N., Bahlmann, E., and Emeis, K.-C.: Influence of diagenesis on sedimentary $\delta^{15} \mathrm{~N}$ in the Arabian Sea over the last $130 \mathrm{ka}$, Mar. Geol., 284, 127-138, https://doi.org/10.1016/j.margeo.2011.03.013, 2011.

Müller, P. J. and Suess, E.: Productivity, sedimentation rate, and sedimentary organic matter in the oceans - I. Organic carbon preservation, Deep-Sea Res., 26, 1347-1362, https://doi.org/10.1016/0198-0149(79)90003-7, 1979.

Müller, P. J., Schneider, R., and Ruhland, G.: Late Quaternary $p \mathrm{CO}_{2}$ variations in the Angola Current: Evidence from organic carbon $\delta^{13} \mathrm{C}$ and alkenone temperature, in: Carbon Cycling in the Glacial Ocean: Constraints on the Ocean's Role in Global
Change, edited by: Zahn, R., Pedersen, T. F., Kaminski, M. A., and Labeyrie, L., NATO ASI Series I, Global Environmental Change, 17, Springer-Verlag, Berlin, Germany, 343-366, 1994.

Murgese, D. S. and De Deckker, P.: The Late Quaternary evolution of water masses in the eastern Indian Ocean between Australia and Indonesia, based on benthic foraminifera faunal and carbon isotopes analyses, Palaeogeogr. Palaeocl., 247, 382-401, https://doi.org/10.1016/j.palaeo.2006.11.002, 2007.

Murray, J. W.: Ecology and Applications of Benthic Foraminifera, Cambridge University Press, New York, USA, 1-426, 2006.

Naik, D. K., Saraswat, R., Lea, D. W., Kurtarkar, S. R., and Mackensen, A.: Last glacial-interglacial productivity and associated changes in the eastern Arabian Sea, Palaeogeogr. Palaeocl., 483, 147-156, https://doi.org/10.1016/j.palaeo.2016.07.014, 2017.

Nair, R. R., Ittekkot, V., Manganini, S. J., Ramaswamy, V., Haake, B., Degens, E. T., Desai, B. N., and Honjo, S.: Increased particle flux to the deep ocean related to monsoons, Nature, 338, 749751, https://doi.org/10.1038/338749a0, 1989.

NASA Goddard Space Flight Center: MODIS-Aqua Ocean Color Data, Ocean Ecology Laboratory, Ocean Biology Processing Group, https://doi.org/10.5067/AQUA/MODIS_OC.2014.0, 2014.

Olson, D. B., Hitchcock, G. L., Fine, R. A., and Warren, B. A.: Maintenance of the low-oxygen layer in the central Arabian Sea, Deep-Sea Res. Pt. II, 40, 673-685, https://doi.org/10.1016/09670645(93)90051-N, 1993.

Pahnke, K. and Zahn, R.: Southern hemisphere water mass conversion with North Atlantic climate variability, Science, 307, 17411746, https://doi.org/10.1126/science.1102163, 2005.

Paillard, D., Labeyrie, L., and Yiou, P.: Macintosh Program Performs Time-Series Analysis, Eos Transactions AGU, 77, 379 379, https://doi.org/10.1029/96EO00259, 1996.

Parker, J. H. and Gischler, E.: Modern foraminiferal distribution and diversity in two atolls from the Maldives, Indian Ocean, Mar. Micropaleontol., 78, 30-49, https://doi.org/10.1016/j.marmicro.2010.09.007, 2011.

Pattan, J. N. and Pearce, N. J. G.: Bottom water oxygenation history in southeastern Arabian Sea during the past $140 \mathrm{ka}$ : Results from redox-sensitive elements, Palaeogeogr. Palaeocl., 280, 396-405, https://doi.org/10.1016/j.palaeo.2009.06.027, 2009.

Paul, A., Reijmer, J. J., Fürstenau, J., Kinkel, H., and Betzler, C.: Relationship between Late Pleistocene sea-level variations, carbonate platform morphology and aragonit production (Maldives, Indian Ocean), Sedimentology, 59, 1640-1658, https://doi.org/10.1111/j.1365-3091.2011.01319.x, 2012.

Pichevin, L., Bard, E., Martinez, P., and Billy, I.: Evidence of ventilation changes in the Arabian Sea during the late Quaternary: Implication for denitrification and nitrous oxide emission, Global Biogeochem. Cy., 21, GB4008, https://doi.org/10.1029/2006GB002852, 2007.

Prasad, T. G. and Ikeda, M.: Seasonal spreading of the Persian Gulf Water mass in the Arabian Sea, J. Geophys. Res., 106, 1705917071, https://doi.org/10.1029/2000JC000480, 2001.

Reichart, G. J., Lourens, L. J., and Zachariasse, W. J.: Temporal variability in the northern Arabian Sea Oxygen Minimum Zone (OMZ) during the last 225000 years, Paleoceanography, 13, 607-621, https://doi.org/10.1029/98PA02203, 1998. 
Reid, J. L.: On the total geostrophic circulation of the Indian Ocean: flow patterns, tracers, and transports, Prog. Oceanogr., 56, 137186, https://doi.org/10.1016/S0079-6611(02)00141-6, 2003.

Reimer, P. J., Bard, E., Bayliss, A., Beck, J. W., Blackwell, P. G., Ramsey, C. B., Buck, C. E., Cheng, H., Edwards, R. L., Friedrich, M., Grootes, P. M., Guilderson, T. P., Haflidason, H., Hajdas, I., Hatté, C., Heaton, T. J., Hoffmann, D. L., Hogg, A. G., Hughen, K. A., Kaiser, K. F., Kromer, B., Manning, S. W., Niu, M., Reimer, R. W., Richards, D. A., Scott, E. M., Southon, J. R., Staff, R. A., Turney, C. S. M., and van der Plicht, J.: IntCal13 and Marine13 Radiocarbon Age Calibration Curves 0-50000 years cal BP, Radiocarbon, 55, 1869-1887, https://doi.org/10.2458/azu_js_rc.55.16947, 2013.

Reolid, J., Reolid, M., Betzler, C., Lindhorst, S., Wiesner, M. G., and Lahajnar, N.: Upper Pleistocene cold-water corals from the Inner Sea of the Maldives: taphonomy and environment, Facies, 63, 1-20, https://doi.org/10.1007/s10347-016-0491-7, 2017.

Rixen, T., Haake, B., Ittekkot, V., Guptha, M. V. S., Nair, R. R., and Schlüssel, P.: Coupling between SW monsoon-related surface and deep ocean processes as discerned from continous particle flux measurements and correlated satellite data, J. Geophys. Res., 101, 28569-28582, https://doi.org/10.1029/96JC02420, 1996.

Roberts, A. P., Rohling, E. J., Grant, K. M., Larrasoaña, J. C., and Liu, Q.: Atmospheric dust variability from Arabia and China over the last 500000 years, Quaternary Sci. Rev., 30, 3537-3541, https://doi.org/10.1016/j.quascirev.2011.09.007, 2011.

Rohling, E. J., Grant, K., Bolshaw, M., Roberst, A. P., Siddall, M., Hemleben, C., and Kucera, M.: Antarctic temperature and global sea level closely coupled over the past ?ve glacial cycles, Nat. Geosci., 2, 500-504, https://doi.org/10.1038/NGEO557, 2009.

Romero, O. E., Kim, J.-H., and Hebbeln, D.: Paleoproductivity evolution off central Chile from the Last Glacial Maximum to the Early Holocene, Quaternary Res., 65, 519-525, https://doi.org/10.1016/j.yqres.2005.07.003, 2006.

Ronge, T. A., Steph, S., Tiedemann, R., Prange, M., Merkel, U., Nürnberg, D., and Kuhn, G.: Pushing the boundaries: Glacial/interglacial variability of intermediate and deep waters in the southwest Pacific over the last 350000 years, Paleoceanography, 30, 23-38, https://doi.org/10.1002/2014PA002727, 2015.

Rostek, F., Bard, E., Beaufort, L., Sonzogni, C., and Ganssen, G.: Sea surface temperature and productivity records for the past $240 \mathrm{ka}$ in the Arabian Sea, Deep-Sea Res. Pt. II, 44, 1461-1480, https://doi.org/10.1016/S0967-0645(97)00008-8, 1997.

Ruddiman, W. F. and Kutzbach, J. E.: Forcing of late Cenozoic northern hemisphere climate by plateau uplift in southern Asia and the American west, Atmospheres, 94, 18409-18427, https://doi.org/10.1029/JD094iD15p18409, 1989.

Rühlemann, C., Müller, P. J., and Schneider, R. R.: Organic carbon and carbonate as paleoproductivity proxies: Examples from high and low productivity areas of the tropical Atlantic, in: Use of proxies in paleoceanography: Examples from the South Atlantic, edited by: Fischer, G. and Wefer, G., Springer, Berlin, Heidelberg, Germany, 315-344, 1999.

Sarkar, S. and Gupta, A. K.: Deep-sea paleoceanography of Maldives Islands (ODP Hole 716A), equatorial Indian Ocean during MIS 12-6, J. Bioscience, 34, 749-764, https://doi.org/10.1007/s12038-009-0066-7, 2009.

Sarkar, S. and Gupta, A. K.: Late Quaternary productivity changes in the equatorial Indian Ocean
(ODP Hole 716A), Palaeogeogr. Palaeocl., 397, 7-19, https://doi.org/10.1016/j.palaeo.2013.12.002, 2014.

Sasamal, S. K.: Island wake circulation off Maldives during boreal winter, as visualised with MODIS derived chlorophyll-a data and other satellite measurements, Int. J. Remote Sens., 28, 891-903, https://doi.org/10.1080/01431160600858459, 2007.

Schlager, W., Reijmer, J. J. G., and Droxler, A.: Highstand Shedding of Carbonate Platforms, J. Sediment. Res., 64B, 270-281, 1994.

Schmiedl, G. and Leuschner, D. C.: Oxygenation changes in the deep western Arabian Sea during the last 190000 years: productivity versus deep-water circulation, Paleoceanography, 20, PA2008, https://doi.org/10.1029/2004PA001044, 2005.

Schmiedl, G. and Mackensen, A.: Multispecies stable isotopes of benthic foraminifers reveal past changes of organic matter decomposition and deepwater oxygenation in the Arabian Sea, Paleoceanography, 21, PA4213, https://doi.org/10.1029/2006PA001284, 2006.

Schmiedl, G., Mackensen, A., and Müller, P. J.: Recent benthic foraminifera from the eastern South Atlantic Ocean: Dependence on food supply and water masses, Mar. Micropaleontol., 32, 249287, https://doi.org/10.1016/S0377-8398(97)00023-6, 1997.

Schoepfer, S. D., Shen, J., Wei, H., Tyson, R. V., Ingall, E., and Algeo, T. J.: Total organic carbon, organic phosphorus, and biogenic barium fluxes as proxies for paleomarine productivity, Earth-Sci. Rev., 149, 23-52, https://doi.org/10.1016/j.earscirev.2014.08.017, 2015.

Schott, F. A. and McCreary Jr., J. P.: The monsoon circulation of the Indian Ocean, Prog. Oceanogr., 51, 1-123, https://doi.org/10.1016/S0079-6611(01)00083-0, 2001.

Schulz, H., von Rad, U., and Erlenkeuser, H.: Correlation between Arabian Sea and Greenland climate oscillation of the past 110000 years, Nature, 393, 54-57, https://doi.org/10.1038/31750, 1998.

Singh, A. D., Jung, S. J. A., Darling, K., Ganeshram, R., Ivanochko, T., and Kroon, D.: Productivity collapses in the Arabian Sea during glacial cold phases, Paleoceanography, 26, PA3210, https://doi.org/10.1029/2009PA001923, 2011.

Sirocko, F. and Lange, H.: Clay-mineral accumulation rates in the Arabian Sea during the late Quaternary, Mar. Geol., 97, 105-119, https://doi.org/10.1016/0025-3227(91)90021-U, 1991.

Smith, A. J. and Gallagher, S. J.: The Recent foraminifera and facies of the Bass Canyon: a temperate submarine canyon in Gippsland, Australia, J. Micropalaeontol., 22, 63-83, https://doi.org/10.1144/jm.22.1.63, 2003.

Southon, J., Kashgarian, M., Fontugne, M., Metivier, B., and Yim, W. W.-S.: Marine Reservoir Corrections for the Indian Ocean and Southeast Asia, Radiocarbon, 44, 167-180, https://doi.org/10.1017/S0033822200064778, 2002.

Stramma, L., Johnson, G. C., Sprintall, J., and Mohrholz, V.: Expanding oxygen-minimum zones in the tropical oceans, Science, 320, 655-658, https://doi.org/10.1126/science.1153847, 2008.

Stuiver, M. and Reimer, P. J.: Extended ${ }^{14} \mathrm{C}$ data base and revised CALIB 3.0 ${ }^{14} \mathrm{C}$ age calibration program, Radiocarbon, 35, 215230, 1993.

Sun, X., Corliss, B. H., Brown, C. W., and Showers, W. J.: The effect of primary productivity and seasonality on the distribution of deep-sea benthic foraminifera in the North Atlantic, Deep-Sea Res. Pt. I, 53, 28-47, https://doi.org/10.1016/j.dsr.2005.07.003, 2006. 
Thiede, J., Nees, S., Altenbach, A., Andresen, N., Findlay, C., Hill, P., Howard, W., Jellinek, T., Jurkschat, T., Laurent, E., van der Lingen, G., Müller, A., Neil, H., Probert, I., Rehder, W., Reijmer, J., Rendle, R., Roth, S., Rueggeberg, A., Runze, O., Schulz, H., Schumann, M., Sturm, A., Swanson, K., and Willamowski, C.: FS Sonne Fahrtbericht SO136, Cruise Report SO136, TASQWA: Quaternary variability of water masses in Southern Tasman sea and the southern ocean (SW pacific sector), Wellington-Hobart, October 16 November 12, GEOMAR Report 89, 1-106, GEOMAR, Kiel, Germany, 1999.

Weiss, R. F., Broecker, W. S., Craig, H., and Spencer, D.: GEOSECS Indian Ocean Expedition: Hydrographic Data 19771978, 5, U.S. Government Printing Office, Washington, D.C., USA, 1-62, 1983.

Wiggert, J. D., Murtugudde, R. G., and Christian, J. R.: Annual ecosystem variability in the tropical Indian Ocean: Results of a coupled bio-physical ocean general circulation model, Deep-Sea Res. Pt. II, 53, 644-676, https://doi.org/10.1016/j.dsr2.2006.01.027, 2006.

Wyrtki, K.: Physical oceanography of the Indian Ocean, in: The biology of the Indian Ocean, edited by: Zeitzschel, B. and Gerlach, S. A., Springer-Verlag, Berlin, Heidelberg, Germany, 1836, 1973.

You, Y.: Intermediate water circulation and ventilation of the Indian Ocean derived from water-mass contributions, J. Mar. Res., 56, 1029-1067, 1998.
Zhang, X., Arimoto, R., An, Z., Chen, T., Zhang, G., Zhu, G., and Wang, X.: Atmospheric trace elements over source regions for Chinese dust: concentrations, sources and atmospheric depositions on the Loess Plateau, Atmos. Environ., 27A, 2051-2067, https://doi.org/10.1016/0960-1686(93)90277-6, 1993.

Zhang, X. Y., Lu, H. Y., Arimoto, R., and Gong, S. L.: Atmospheric dust loadings and their relationship to rapid oscillations of the Asian winter monsoon climate: two 250-ka loess records, Earth Planet. Sc. Lett., 202, 637-643, https://doi.org/10.1016/S0012821X(02)00797-5, 2002.

Ziegler, M., Jilbert, T., de Lange, G., Lourens, L. J., and Reichart, G.-J.: Bromine counts from XRF scanning as an estimate of the marine organic carbon content of sediment cores, Geochem. Geophy. Geosy., 9, 1-6, https://doi.org/10.1029/2007GC001932, 2008.

Ziegler, M., Lourens, L. J., Tuenter, E., and Reichart, G.-J.: Anomalously high Arabian Sea productivity conditions during MIS 13, Clim. Past Discuss., 5, 1989-2018, 2009.

Ziegler, M., Lourens, L. J., Tuenter, E., and Reichart, G.-J.: High Arabian Sea productivity conditions during MIS 13 odd monsoon event or intensified overturning circulation at the end of the Mid-Pleistocene transition?, Clim. Past, 6, 63-76, https://doi.org/10.5194/cp-6-63-2010, 2010. 